\title{
Assessment of impacts of agricultural and climate change scenarios on watershed water quantity and quality, and crop production
}

\author{
Awoke D. Teshager ${ }^{1}$, Philip W. Gassman ${ }^{2}$, Justin T. Schoof ${ }^{3}$, and Silvia Secchi ${ }^{3}$ \\ ${ }^{1}$ Graham Sustainability institute, University of Michigan, 214 S State St., Suite 200, Ann Arbor, MI 48104, USA \\ ${ }^{2}$ Department of Economics, Center for Agricultural and Rural Development, Iowa State University, 560A Heady Hall, \\ Ames, IA 50011, USA \\ ${ }^{3}$ Geography and Environmental Resources, Southern Illinois University Carbondale; Faner Hall, Carbondale, IL 62901, USA
}

Correspondence to: Awoke D. Teshager (awoke@umich.edu)

Received: 19 February 2016 - Published in Hydrol. Earth Syst. Sci. Discuss.: 10 March 2016

Revised: 30 June 2016 - Accepted: 19 July 2016 - Published: 15 August 2016

\begin{abstract}
Modeling impacts of agricultural scenarios and climate change on surface water quantity and quality provides useful information for planning effective water, environmental and land use policies. Despite the significant impacts of agriculture on water quantity and quality, limited literature exists that describes the combined impacts of agricultural land use change and climate change on future bioenergy crop yields and watershed hydrology. In this study, the soil and water assessment tool (SWAT) ecohydrological model was used to model the combined impacts of five agricultural land use change scenarios and three downscaled climate pathways (representative concentration pathways, RCPs) that were created from an ensemble of eight atmosphere-ocean general circulation models (AOGCMs). These scenarios were implemented in a wellcalibrated SWAT model for the intensively farmed and tiled Raccoon River watershed (RRW) located in western Iowa. The scenarios were executed for the historical baseline, early century, mid-century and late century periods. The results indicate that historical and more corn intensive agricultural scenarios with higher $\mathrm{CO}_{2}$ emissions consistently result in more water in the streams and greater water quality problems, especially late in the 21 st century. Planting more switchgrass, on the other hand, results in less water in the streams and water quality improvements relative to the baseline. For all given agricultural landscapes simulated, all flow, sediment and nutrient outputs increase from early-tolate century periods for the RCP4.5 and RCP 8.5 climate scenarios. We also find that corn and switchgrass yields are neg-
\end{abstract}

atively impacted under RCP4.5 and RCP8.5 scenarios in the mid- and late 21 st century.

\section{Introduction}

Land use change and climate change are at the forefront of various pressures that are expected to alter 21st century land ecosystems (Ostberg et al., 2015; Heffernan et al., 2014; Howells et al., 2013; Moore et al., 2012). Both factors have been shown to independently or collectively greatly impact watershed hydrology and/or water quality across a tremendous range of scales, as shown in literally hundreds of studies in existing literature (e.g., Wilson and Weng, 2011; Jha et al., 2006, 2010; Secchi et al., 2011; Panagopoulos et al., 2015; Tan et al., 2015; Mehdi et al., 2015a, b). These land use and climate change impacts pose potentially serious issues for specific communities (Kundzewicz et al., 2007) as well as for large regions or whole countries (Heffernan et al., 2014; Howells et al., 2013; Moore et al., 2012). Thus, it is urgent to evaluate the potential impacts of combined future land use and climate change on different ecosystems, hence planning effective water, environmental, and land use policies (Heffernan et al., 2014).

Key agricultural production regions are critical ecosystems that may be adversely impacted by future land use change and climate change (Moore et al., 2012; Howells et al., 2013). An important component of likely future agricultural land use change is the increased development of biofuel cropping systems, which are projected to require 37 mil- 
lion ha by the year 2030 (Howells et al., 2013). Extensive expansion of the biofuel industry has occurred in the US Corn Belt region, primarily in the form of corn grain-based ethanol (RFA, 2016). Several studies report the potential of increased water quality problems or other ecosystem degradation due to the expansion of corn production in the Corn Belt region (e.g., Donner and Kucharik, 2008; Simpson et al., 2008; Jha et al., 2010; Secchi et al., 2011; Wright and Wimberly, 2013). These potential problems underscore the need to investigate the environmental impacts of more widespread adoption of advanced perennial biofuel crops such as switchgrass, which has been found to provide multiple environmental benefits including carbon sequestration, soil water nutrient scavenging, remediating contaminated soil and/or providing a suitable habitat for grassland birds (Khanna et al., 2008; Secchi et al., 2008; Vadas, 2008; Keshwani and Cheng, 2009). Schmer et al. (2008) investigated the net energy of cellulosic ethanol made from switchgrass over a 5-year time period and found that switchgrass ethanol production resulted in $540 \%$ more renewable than nonrenewable energy consumed and $94 \%$ fewer greenhouse gas (GHG) emissions than gasoline production. Vadas et al. (2008) further suggested that switchgrass may be best suited in highly erodible lands, considering its environmental benefits, in investigating the economics and energy of ethanol production from alfalfa, corn and switchgrass. Moreover, various researchers have shown the benefit of switchgrass in reducing sediment and nutrient yields from cropland landscapes (e.g., Schilling et al., 2008; Wu et al., 2012; Zhou et al., 2015).

A variety of tools have been developed that can be used to investigate the impacts of climate change and/or land use change in agricultural ecosystems including the soil and water assessment tool (SWAT) eco-hydrological model (Arnold et al., 1998, 2012; Williams et al., 2008). SWAT has been used worldwide to investigate an extensive array of hydrological and/or pollutant transport problems across a wide range of watershed scales (Gassman et al., 2007, 2014; Krysanova and White, 2015; Bressiani et al., 2015; Gassman and Wang, 2015). An extensive review of earlier SWAT literature revealed that applications of the model for climate change and land use scenarios were two of the key application trends occurring at that time (Gassman et al., 2007). More recent reviews of SWAT literature confirm that this trend has continued unabated (Krysanova and White, 2015; Gassman et al., 2014) and current documentation of the SWAT literature indicates that roughly 500 studies describe some type of climate change application while over 300 studies report the effects of land use change (CARD, 2016).

An emerging trend in this overall subset of SWAT literature is the application of the model for combined climate change and land use change impacts (Krysanova and White, 2015; Gassman et al., 2014); over 70 combined impact studies have now been documented (CARD, 2016). Such studies first were reported for Chinese conditions ( $\mathrm{Li}$ et al., 2004), which now include applications focused on capturing the ef- fects of historical land use change due to the influence of Chinese government programs (Zuo et al., 2016; G. H. Liu et al., 2015; W. Liu et al., 2015) and scenarios that reflect hypothetical shifts between various percentages of urban, forest, agricultural and other land use (Zhang et al., 2015, 2016; Wu et al., 2015). Similar types of combined SWAT climate change/land use change studies have been performed in other regions including Asia (Sayasane et al., 2015; Singkran et al., 2015; Tan et al., 2015), Europe (Serpa et al., 2015; Mehdi et al., 2015b; Guse et al., 2015) and North America (Mehdi et al., 2015a; Neupane and Kumar, 2015; Goldstein and Tarhule, 2015).

Several SWAT studies have focused specifically on the combined impacts of climate change and land use change on hydrological and/or pollutant responses within an agricultural context. Mehdi et al. (2015a, b) describe similar methodologies of analyzing future agricultural land use and management scenarios for forecasted land use for watersheds that drain portions of Québec and Vermont, or an area in the Bavarian region of Germany, in conjunction with projected future climate change. Guse et al. (2015) discussed the impacts of three land use scenarios, which represent shifts in cropping and grassland allocations, in combination with a RCM projection on future macroinvertebrate and fish habitat for a watershed in northern Germany. Neupane and $\mathrm{Ku}-$ mar (2015) reported the impacts of expanded corn production within projected late 21 st century climate conditions for a watershed in eastern South Dakota. Other studies (Wu et al., 2013; Hoque et al., 2014; Goldstein and Tarhule, 2015) described the impacts of introducing perennial bioenergy crops within cropland landscapes for varying predicted future climate conditions for watersheds located in the US Corn Belt or Great Plains regions. Collectively, these studies reveal that hydrologic and pollutant transport characteristics for cropland landscapes can be very sensitive to shifts in land use and/or climate.

A complex set of factors drives cropping system decisions for a given Corn Belt region land parcel including crop prices, land productivity, previous years' profits, costs for fertilizer, energy, pesticides and other inputs, neighbors' choices, government programs and available markets for supporting production of a specific crop. Future development of infrastructure would need to occur to support perennial bioenergy crop production in the Corn Belt region. In contrast, three cellulosic ethanol plants are being developed or are in operation in the Corn Belt region that rely on corn stover (Peplow, 2014; ENERGY.GOV, 2015), a trend that could drive even more demand for corn production. Thus, Additional research is needed to ascertain the hydrologic and water quality impacts of possible increased corn production vs. perennial biofuel crop adoption within projected future climate conditions for Corn Belt region stream systems.

Thus, the focus of this study is to investigate the combined hydrologic and water quality impacts of potential future bioenergy crop production and projected future climate 
change for cropland landscapes of the Raccoon River watershed (RRW) located in western Iowa. The RRW is characterized by intensive row crop agriculture dominated by corn and soybean production, widespread use of subsurface tile drainage systems within flatter cropland landscapes and intensive nitrogen and phosphorus inputs in the form of inorganic fertilizers and livestock manure. The Des Moines Water Works (DMWW), the largest such system in Iowa, relies on the Raccoon River as a key source of drinking water for Des Moines metropolitan area. The DMWW was forced to build what is believed to be the world's largest nitrate removal facility in 1991 in order to meet US federal drinking water standards (White, 1996; DMWW, 2015) and operated the facility a record-breaking 111 days in 2015 . The DMWW also filed a law suit against three upstream Iowa counties in the watershed for their excessive nitrate load to the Raccoon River.

Several previous studies have been conducted for the RRW stream system with SWAT to investigate the hydrologic and water quality impacts of alternative cropping systems including systems consisting solely of perennial grasses, such as switchgrass, and/or the inclusion of alfalfa in rotation with row crops (Schilling et al., 2008; Jha et al., 2010; Gassman et al., 2015). Jha and Gassman (2014) further investigated the impacts of potential future climate change on RRW hydrology using an ensemble of 10 atmosphere-ocean general circulation models (AOGCMs) and typical cropping systems consisting of rotations of corn and soybean. However, analysis of the combined effects of agricultural land use change and climate change are currently lacking for the RRW and for the Corn Belt region in general, especially in the context of evaluating the impacts of potential biofuel cropping systems. To address this gap, a SWAT analysis is performed in this study for the RRW that incorporates five agricultural scenarios, three 21 st century future climate periods (early, mid- and late), and three GHG emission pathways (RCP2.6, RCP4.5 and RCP8.5) that were represented within an ensemble of eight AOGCMs that were included in Phase 5 of the Coupled Model Intercomparison Project (CMIP5) (Taylor et al., 2012). The analysis is performed using an improved RRW SWAT model (Teshager et al., 2015) that allows for analysis of typical row crop and/or perennial biofuel cropping systems at a refined spatial scale representative of field-level land parcels. Thus, the objectives of this study are to (1) describe the methodology used to develop the combined agricultural land use change and future climate change projections, and (2) quantify the effects of the combined scenarios on future RRW hydrology, water quality and crop yields.

\section{Study area}

The RRW drains a total area of $9393 \mathrm{~km}^{2}$ from portions of 17 counties in western central Iowa (Fig. 1). The RRW is also composed of two 8-digit watersheds as defined by the

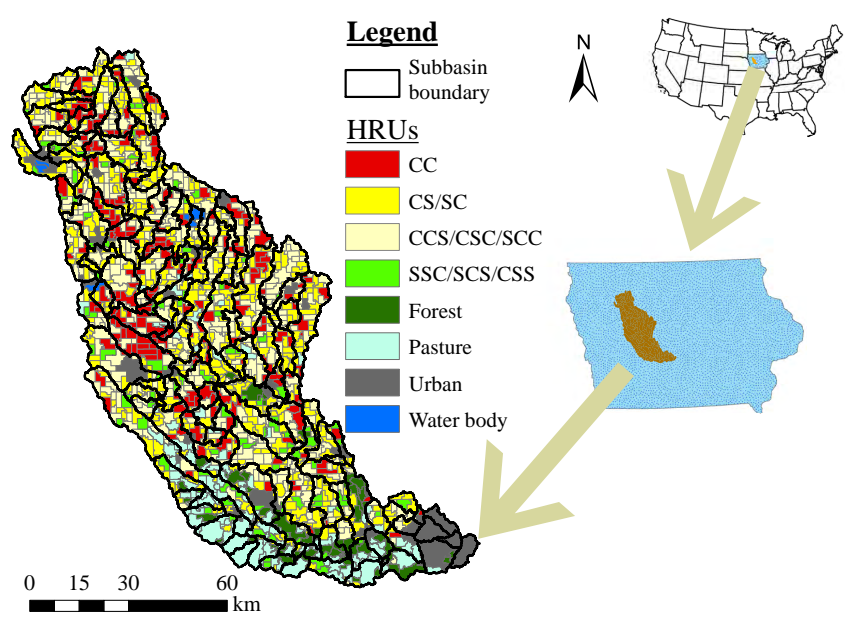

Figure 1. The RRW with its historical (baseline) land use (CC is continuous corn rotation, CS/SC is corn-soybeans rotation, $\mathrm{CCS} / \mathrm{CSC} / \mathrm{SCC}$ is 2 years of corn and 1 year of soybeans in 3-year rotation, SSC/SCS/CSS is 2 years of soybeans and 1 year of corn in 3-year rotation).

US federal watershed classification system (USGS, 2013), which are referred to as the north Raccoon and south Raccoon watersheds. The north Raccoon watershed is dominated by flat land and poor surface drainage, whereas the south Raccoon watershed is characterized by higher slopes, steeply rolling hills and well-developed drainage (Agren, 2011). Fertilizer and livestock manure applications on cropland are key sources of nutrients in the RRW stream system. The extensive tile drain systems that have been established in the north Raccoon region are important conduits of nitrate to the RRW stream system.

The RRW is an intensively farmed region dominated by corn and soybean production. Cropland comprises about $79 \%$ of the watershed (Teshager et al., 2015) followed by pasture/grass $(10 \%)$, developed areas $(6 \%)$, mixed forest (4.4) and water bodies $(0.5 \%)$. The watershed has a humid climate with both cold and hot extremes, similar to most of the Midwest region. The average temperature in summer is about $22.7^{\circ} \mathrm{C}$ and in winter is about $-4.6{ }^{\circ} \mathrm{C}$. Large variations in annual precipitation are very common. The annual precipitation varied from $606 \mathrm{~mm}$ in 1984 to $1372 \mathrm{~mm}$ in 1993 , and the average annual precipitation was $829 \mathrm{~mm}$, for the 30-year period of 1981 to 2010 . About $75 \%$ of the precipitation falls in the months of April through September and peak monthly precipitation typically occurs within that period. Teshager et al. (2015) estimated that, based on data from Iowa Department of Natural Resources (IDNR), about $57 \%$ of the watershed ( $\sim 72 \%$ of the agricultural land) has tile drainage and $20 \%$ of the watershed receives manure application. 


\section{Simulations}

\subsection{Model description and setup}

SWAT2012/Release 622 was the version of the model used for this study. SWAT is dynamic model that is typically executed on a daily time step, although sub-daily options are also provided. The model is comprised of climate, soil, hydrology, management, nutrient cycling and transport, pesticide fate and transport, and several other components. Release 622 also features enhanced algorithms that account for more accurate representation of important switchgrass and miscanthus growth phenomena related to belowground biomass, plant respiration and nutrient uptake, which were developed by Trybula et al. (2015) and ported to standard SWAT versions starting with SWAT2012/release 615. A watershed is typically delineated into subbasins in SWAT, based on topography, and each subbasin is then divided into multiple hydrological response units (HRUs), which consist of homogeneous soil, land use, topographic and management characteristics (Neitsch et al., 2011; Arnold et al., 2012). At present, HRUs are not spatially identified in applications of standard versions of SWAT although incorporation of expanded spatial detail is being developed (Duku et al., 2015; Arnold et al., 2010). Water and pollutants discharged at the HRU level are input at the respective subbasin outlet and routed through the stream system to the watershed outlet. Neitsch et al. (2011) and Arnold et al. (2012) provided additional details about specific SWAT components, functions and/or input data requirements.

Baseline model testing (Teshager et al., 2015) was performed using 10 weather stations distributed fairly uniformly across the watershed, and streamflow and in-stream pollutant data measured at a gauge located near Van Meter, which drains $95 \%$ of the RRW. The model was calibrated and validated for the RRW for the years 2002 to 2010 for flow, total suspended solids (TSS), nitrate $\left(\mathrm{NO}_{3}\right)$ and mineral phosphorus (MINP) at daily, monthly and annual timescales (Teshager et al., 2015). Land use/land cover (LULC) from the USDA Cropland Data Layer (CDL; USDA-NASS, 2012) for the years 2002 to 2010 was used to develop crop rotations for calibration/validation of the watershed. According to Teshager et al. (2015), about $14 \%$ of the watershed was planted in continuous corn (CC), $30 \%$ was in 3year rotations with 1 year of soybean and 2 years of corn (CCS/CSC/SCC), $31 \%$ was in 2-year corn-soybean rotations $(\mathrm{CS} / \mathrm{SC}), 6 \%$ was in 3-year rotations consisting of 2 years of soybean and 1 year of corn (SSC/SCS/CSS), and $10 \%$ was pasture/grass (Fig. 1). The rest of the watershed included developed areas, forest or water bodies. The SWAT model was able to replicate flow, $\mathrm{TSS}, \mathrm{NO}_{3}$ and MINP satisfactorily at daily, monthly and annual timescales.

\subsection{Agricultural scenarios}

The most common approach in assessing climate change impacts is scenario construction (Öborn et al., 2011). The objective of a specific scenario, and the subject's complexity and time horizon shapes the method chosen for constructing scenarios (Dreborg, 2004). Due to the absence of a direct method for predicting future farming choices, the agricultural scenarios developed in this study were developed based mainly on the need for more corn production for food, livestock feed and biofuel production, and the promising potential of switchgrass (SWG) for bio-energy production (Khanna et al., 2008; Schmer et al., 2008; Secchi et al., 2008; Vadas et al., 2008). Accordingly, five agricultural scenarios were considered for the overall impact analysis (Table 1).

The first scenario considered in this study assumed that future agricultural land use (crop type and rotation) matches historical agricultural land use patterns and is referred to as the baseline (BL) scenario. In addition to crop types and rotations, fertilizer/manure applications, tillage practices and tile drainage were held constant through all three future simulation periods. Hence, the distributions of crop rotations described in the "Model description and setup" section and Fig. 1, as well as with the management practices stated in Table 2, were used for the BL simulations.

The second scenario reflects projections developed by the US Department of Agriculture (USDA) that demand for corn will increase in the future based on an analysis of the world's agricultural sector in general and the US agricultural sector in particular for the next decade (USDA-NASS, 2015). According to this report, US corn acreage is projected to remain high and production to rise gradually taking all uses of corn into account. Thus, this scenario is termed partialcorn (PC) and is simulated by converting selected HRUs into $\mathrm{CC}$, as a function of baseline crop rotation, land use, and topographical conditions, accommodating the projected increase in corn production. All baseline CCS/CSC/SCC rotations were converted to $\mathrm{CC}$, due to the fact that those land parcels were already managed with relatively intense corn production. Next, pasture HRUs with an average slope less than or equal to the current maximum cropland average slope were converted to CC; the slope constraint prevented conversion of extremely high sloped pasture land. About $52 \%$ of the watershed was planted in CC for this scenario, $\mathrm{CS} / \mathrm{SC}$ and SSC/SCS/CSS rotations percentages remained the same, and about $2 \%$ of the watershed was still under pasture (Fig. 2a). Fertilizer applications to corn for CC cropping systems was $202 \mathrm{~kg} \mathrm{Nha}^{-1}$ and $65 \mathrm{~kg} \mathrm{Pha}^{-1}$ (as recommended by Duffy, 2013), in combination with conventional tillage, for the HRUs that were changed from other rotations or land uses to the $\mathrm{CC}$ rotation. The presence of tile drainage was held constant relative to the baseline scenario.

The third scenario reflects adoption of switchgrass on selected RRW HRUs and is called the partial switchgrass (PS) scenario. The HRUs selected for this scenario were chosen 
Table 1. Percentage of crop rotations and LULC in each agricultural scenario considered (BL is Baseline, PC is partial corn, AC is all corn, PS is partial switchgrass, AS is all switchgrass).

\begin{tabular}{lrrrrrrrrr}
\hline $\begin{array}{l}\text { Agricultural } \\
\text { scenario }\end{array}$ & CC & CCS/CSC/SCC & CS & SSC/SCS/CSS & SWG & PAST & FRST & WATR & URHD \\
\hline BL & 13.8 & 29.0 & 30.6 & 5.8 & 0.0 & 10.0 & 4.4 & 0.5 & 5.9 \\
PC & 51.3 & 0.0 & 30.6 & 5.8 & 0.0 & 1.5 & 4.4 & 0.5 & 5.9 \\
AC & 89.2 & 0.0 & 0.0 & 0.0 & 0.0 & 0.0 & 4.4 & 0.5 & 5.9 \\
PS & 9.8 & 18.6 & 18.0 & 1.7 & 41.1 & 0.0 & 4.4 & 0.5 & 5.9 \\
AS & 0.0 & 0.0 & 0.0 & 0.0 & 89.2 & 0.0 & 4.4 & 0.5 & 5.9 \\
\hline
\end{tabular}

Table 2. Fertilizer/manure application rates and presence of tiles and tillage practices (SOYB is soybeans, NT is no-till, Cs is conservation tillage, $\mathrm{Cv}$ is conventional tillage).

\begin{tabular}{|c|c|c|c|c|c|c|}
\hline \multirow[t]{2}{*}{ Crop type } & \multirow[t]{2}{*}{ Rotation } & \multicolumn{2}{|c|}{ Fertilizer } & \multirow{2}{*}{$\begin{array}{r}\text { Manure } \\
\left(\mathrm{kg} \mathrm{Nha}^{-1}\right)\end{array}$} & \multirow[t]{2}{*}{ Tile } & \multirow[t]{2}{*}{ Tillage } \\
\hline & & $\mathrm{kg} \mathrm{N} \mathrm{ha}^{-1}$ & $\mathrm{~kg} \mathrm{Pha}^{-1}$ & & & \\
\hline \multirow[t]{2}{*}{ CORN } & CORN after CORN & 165 & 65 & 179 & Yes & $\mathrm{NT}, \mathrm{Cs}, \mathrm{Cv}$ \\
\hline & CORN after SOYB & 150 & 70 & & & \\
\hline \multirow[t]{2}{*}{ SOYB } & SOYB after CORN & 15 & 55 & 0 & & \\
\hline & SOYB after SOYB & 0 & 0 & & & \\
\hline
\end{tabular}

Source: Teshager et al. (2015).

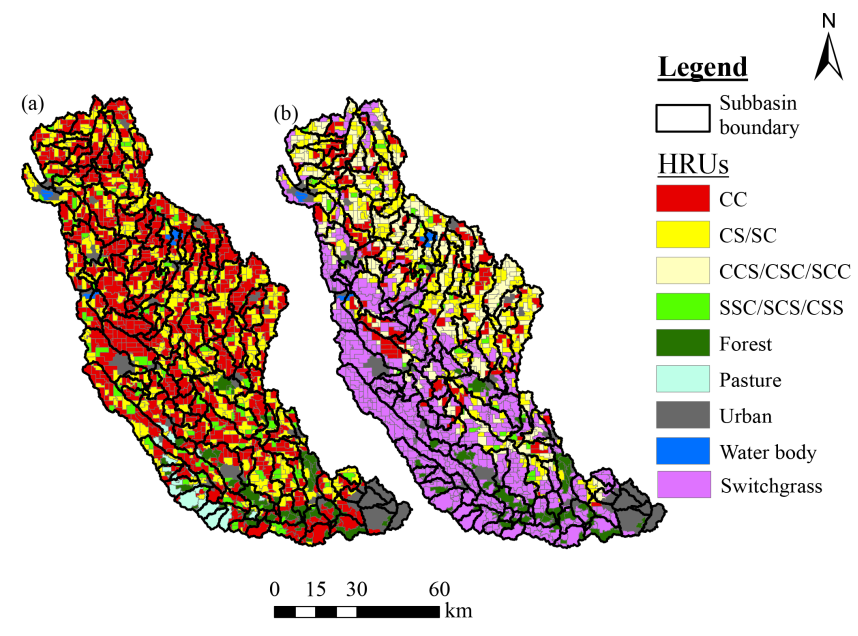

Figure 2. (a) Partial corn and (b) partial switchgrass agricultural scenarios (CC is continuous corn rotation, CS/SC is corn-soybeans rotation, CCS/CSC/SCC is 2 years of corn and 1 year of soybeans in 3-year rotation, SSC/SCS/CSS is 2 years of soybeans and 1 year of corn in 30-year rotation).

based on baseline land use and topographical conditions. First, all pasture HRUs in the baseline scenario were converted to switchgrass. Moreover, cropland HRUs with an average slope of greater than or equal to the average slope of pasture in the baseline were changed to switchgrass, to maximize environmental benefits of converted cropland. Accordingly, about $41 \%$ of the watershed was converted to switchgrass in this scenario, resulting in decreases of $29,34,42$ and $69 \%$ in $\mathrm{CC}, \mathrm{CCS} / \mathrm{CSC} / \mathrm{SCC}, \mathrm{CS} / \mathrm{SC}$ and $\mathrm{SSC} / \mathrm{SCS} / \mathrm{CSS}$ relative to the BL scenario. As a result, about 10, 19, 18 and $2 \%$ of the remaining cropland was partitioned between $\mathrm{CC}, \mathrm{CCS} / \mathrm{CSC} / \mathrm{SCC}, \mathrm{CS} / \mathrm{SC}$ and SSC/SCS/CSS, respectively (Fig. 2b). A nitrogen fertilizer application of $90 \mathrm{~kg} \mathrm{ha}^{-1}$ was simulated for all converted cropland planted to switchgrass based on recommendations by Duffy (2008), Schumer et al. (2008), and McLaughlin and Kszos (2005). Tillage practices are not part of a perennial switchgrass cropping system and thus no till was the simulated tillage level by default. The PS scenario criteria underscore that the most productive corn-dominated cropland is located in very low slope areas.

The final two scenarios feature extreme conversions of all cropland and pasture land, representing $90 \%$ of the RRW, to either CC (all corn scenario or AC) or switchgrass (all switchgrass or AS). The same respective fertilizer and tillage assumptions described for the PC and PS scenarios were also used for these two scenarios.

The last two scenarios bracket hypothetical extreme future land use changes in the watershed and represent the extent of the possible trade offs in food and fuel production, water quality and water quantity. The two partial scenarios are more realistic and illustrate potential land use changes at a very fine resolution associated with climate change, global market forces, and energy and conservation policies. For example, the PS scenario could be associated with very aggressive climate mitigation and conservation policies, and the effective deployment of cellulosic ethanol and the corresponding phasing of corn ethanol. 


\subsection{Climate projections}

The climate projections were developed by downscaling output from multiple coupled AOGCMs to the locations of watershed weather stations. AOGCMs represent the primary tools available to assess the large-scale climatic response to changes in forcing such as the expected changes in 21st century greenhouse gas concentrations. In this study, eight AOGCMs (Table 3), which were all included in CMIP5 (Taylor et al. 2012), were utilized in developing climate change projections for the RRW land use change scenario simulations. Using AOGCM ensembles incorporates information from different models, often increasing the value of the climate information obtained (Knutti et al., 2010; Martre et al., 2015; Pierce et al., 2009; Weigel et al., 2010) and thus an improved overall climate change impact analysis.

Each of these eight climate models were forced with three representative concentration pathways (RCPs) representing low (RCP2.6), medium (RCP4.5) and high (RCP 8.5) levels of radiative forcing from GHGs (Moss et al., 2010; van Vuuren et al., 2011a). The RCP2.6 pathway depicts future conditions, which represent a "medium development" of global population, income and energy use and land use, resulting in a peak atmospheric $\mathrm{CO}_{2}$ concentration prior to 2100 (van Vuuren et al., 2011a, b). A cost-minimizing approach is used in the RCP4.5 pathway, which assumes that simultaneous efforts occur worldwide to mitigate emissions, including taking into account the cost of reducing emissions per the 100-year warming potential of a respective GHG, resulting in stabilization of atmospheric $\mathrm{CO}_{2}$ concentrations in 2100 (Thomson et al., 2011; van Vuuren et al., 2011a). High energy demand and GHG emissions characterize the RCP8.5 pathway, which occur due to an assumed high population and slow income growth with modest rates of technological change and energy improvement, without implementation of climate change adaptation policies (Riahi et al., 2011; van Vuuren et al., 2011a).

The PC and AC agricultural scenarios reflect land use patterns, management systems and energy use levels that could potentially contribute to higher GHG emissions (Davis et al., 2012), which would be consistent with the RCP8.5 pathway. Planting switchgrass, on the other hand, has a potential to sequester carbon (Keshwani and Cheng, 2009; Davis et al., 2012) and help reduce $\mathrm{CO}_{2}$ emission in the long term. Thus the AC scenario could be viewed as being consistent with the RCP8.5 pathway and the AS scenario could be considered as a system consistent with the RCP2.6 pathway, due to expected lower GHG emissions that would occur during the next century due to the expanded switchgrass production. These hypothetical relationships between the future agricultural scenarios and the RCP pathways are investigated to some extent per the interactions of different agricultural scenarios and climate projections in the Results and discussions section.
Contemporary AOGCMs are archived with a resolution of approximately $2^{\circ}$, although there is substantial variability in model resolution among participating modeling groups. To conduct impact analysis using models like SWAT, higherresolution information is required. Thus, downscaling to a finer resolution is crucial to incorporate local climate variability for detailed watershed assessments. Here, a statistical downscaling approach involving regression-based models and stochastic weather simulation, as described by Schoof et al. (2007) and Schoof (2010), was used to derive stationbased projections consistent with the projections of the parent AOGCMs under each emissions pathway. These downscaled climate data were then post-processed to produce a comprehensive daily weather data set (precipitation, minimum and maximum temperature, relative humidity, solar radiation and wind speed) for the years 2011 to 2100 to be used in the SWAT model scenario simulations.

In addition to the three emission scenarios (RCPs), the weather data were divided into three temporal blocks of 20 years to represent early (2016-2035), mid- (2046-2065) and late (2076-2095) century climate conditions. As a result, a total of 72 (8 climate models $\times 3$ emission scenarios $\times 3$ temporal scenarios) climate scenarios were created. Moreover, simulating climate change scenarios in SWAT requires the $\mathrm{CO}_{2}$ concentration for the simulation time periods. Accordingly a single average value of $\mathrm{CO}_{2}$ concentration was used in simulating each 20-year temporal block, similar to the approach used by Ficklin et al. (2009), for a given RCP scenario (Table 4). These scenarios were used to run simulations through the calibrated SWAT model for each agricultural scenario discussed in the "Model description and setup" section at the annual timescale.

\subsection{Method of analysis}

Reporting SWAT output values for each year was not feasible due to the fact that 360 total land use change and climate change combinations (72 climate $\times 5$ agricultural scenarios) were simulated in the study. Therefore, annual average and standard deviation values for each temporal block (early, mid- and late century), RCP pathway (2.6, 4.5 and 8.5) and agricultural land use change scenario were reported for each output indicator of interest: streamflow $(Q)$, TSS, total nitrogen (TN) and total phosphorous (TP). This approach allowed us to capture both the trends across temporal blocks and agricultural scenarios, and variations within temporal blocks and across climate models. Moreover, the predicted average corn and switchgrass yields were also determined for each temporal block (consisting of eight climate models) for the $\mathrm{AC}$ and AS agricultural scenarios, respectively. 
Table 3. AOGCMs considered in this study.

\begin{tabular}{lll}
\hline Model name & Modeling center (or group) & Reference \\
\hline BCC-CSM1 & $\begin{array}{l}\text { Beijing Climate Center, China Meteorological Administration } \\
\text { College of Global Change and Earth System Science, Beijing } \\
\text { BNU-ESM }\end{array}$ & $\begin{array}{l}\text { Wu et al. (2010) } \\
\text { Ji et al. (2014) }\end{array}$ \\
CanESM2 & $\begin{array}{l}\text { Canadian Centre for Climate Modelling and Analysis } \\
\text { Centre National de Recherches Meteorologiques/Centre Eu- }\end{array}$ & Chylek et al. (2011) \\
CNRM-CM5 & $\begin{array}{l}\text { Voldoire et al. (2013) } \\
\text { ropeen de Recherche et Formation Avancees en Calcul Scien- }\end{array}$ & \\
tifique & Dufresne et al. (2013) \\
IPSL-CM5A & Institut Pierre-Simon Laplace & Jungclaus et al. (2010) \\
MPI-ESM & Max Planck Institute for Meteorology & Yukimoto et al. (2012) \\
NORI-CGCM3 & Meteorological Research Institute & Kirkevåg et al. (2008) \\
\hline
\end{tabular}

Table 4. Carbon dioxide concentration (ppm) values used in SWAT simulations.

\begin{tabular}{lccc}
\hline Scenario & Early century & Mid-century & Late century \\
\hline RCP2.6 & 418 & 441 & 429 \\
RCP4.5 & 424 & 495 & 532 \\
RCP8.5 & 436 & 578 & 804 \\
\hline
\end{tabular}

\section{Results and discussions}

\subsection{Weather}

Table 5 shows a comparison between historical-observed and future projected average annual precipitation and annual average temperature values along with standard deviations across the years and among AOGCMs. The results show that, on average, annual precipitation and temperature values increase from early to late century (and from RCP2.6 to RCP8.5). Compared to the average historical observations between the years 1991 and 2010, the annual average temperature values for the RCP2.6, RCP4.5 and RCP8.5 pathways within the early, mid- and late century time periods all increased by $1.5-4.2^{\circ} \mathrm{C}$ (Fig. 3), depending on the RCP and time period. In contrast, there were decreases in average annual precipitation values for all of the scenarios except the late century RCP4.5 and RCP 8.5 scenarios (Fig. 3).

Similar results have been reported in previous studies. Chien et al. (2013) reported that, compared to 1990-1999, the average temperature increased by up to $\sim 3{ }^{\circ} \mathrm{C}\left(\sim 5^{\circ} \mathrm{C}\right)$ for 2051-2060 (2086-2095) and the percentage change in annual precipitation was about -28 to $+8 \%(-33$ to $+16 \%)$ for 2051-2060 (2086-2095), using data from nine GCMs (general circulation models) for four watersheds, which cover portions of Illinois, Indiana and Wisconsin. Similarly, Ficklin et al. (2013) analyzed downscaled temperature and precipitation projections from $16 \mathrm{GCMs}$ (two emission scenarios, low (B1) and high (A2)) for Mono Lake basin, California, and found that the 2070-2099 annual average tem-
Precipitation and temperature changes from historical-REVHYHG(1991-2010) values

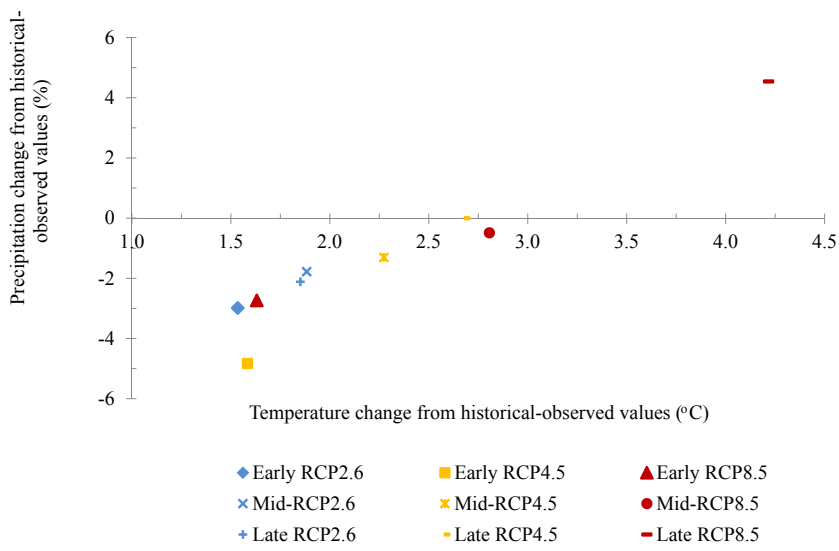

Figure 3. Average annual precipitation and temperature changes for the three RCP scenarios in early, mid and late century compared to historical-observed (1991-2010) values.

perature increased by 2.5 and $4.1^{\circ} \mathrm{C}$ for $\mathrm{B} 1$ and $\mathrm{A} 2$ scenarios, respectively, compared to 1961-1990. However, they also reported that there was a slight but statistically insignificant decrease in annual precipitation on average. These previous studies confirm the results found here that there is a consistent trend of increases in temperature across climate models and geographical locations, while precipitation could increase or decrease depending on the choice of AOGCMs, projection pathway and geographical location of the analysis.

The interannual variation (standard deviation) was much higher ( $\leq$ factor of 4 ) for the historical-observed temperature and precipitation vs. the corresponding future projections (Table 5). The variations among climate models increased for both temperature and precipitation from early to late century. Moreover, the standard deviations among AOGCMs were higher than ( $\geq$ factor of 2 ) the interannual variations for annual average temperature values. Chapman and Walsh (2007) found similar differences between models and interannual variabilities (standard deviation) of temperature using 14 
Table 5. Mean and standard deviations of average annual temperature and precipitation values for historical observed and ensembles of eight climate models used in this study ( $T_{\mathrm{avg}}$ is annual average temperature, PCP is average annual precipitation $T_{\mathrm{avg}, \mathrm{SD}}$ is standard deviation of annual average temperature, $\mathrm{PCP}_{\mathrm{SD}}$ is standard deviation of average annual precipitation).

\begin{tabular}{|c|c|c|c|c|c|c|c|}
\hline \multirow[t]{2}{*}{ Century } & \multirow[t]{2}{*}{ Scenario } & \multirow[t]{2}{*}{$T_{\text {avg }}\left({ }^{\circ} \mathrm{C}\right)$} & \multirow[t]{2}{*}{$\mathrm{PCP}(\mathrm{mm})$} & \multicolumn{2}{|c|}{ Among 8 models } & \multicolumn{2}{|c|}{ Across 20 years } \\
\hline & & & & $T_{\text {avg,SD }}$ & $\mathrm{PCP}_{\mathrm{SD}}$ & $\mathrm{T}_{\mathrm{avg}, \mathrm{SD}}$ & $\mathrm{PCP}_{\mathrm{SD}}$ \\
\hline Historical (1991-2010) & Observed & 9.2 & 831.1 & NA & NA & 0.77 & 175.7 \\
\hline \multirow[t]{3}{*}{ Early (2016-2035) } & $\mathrm{RCP} 2.6$ & 10.7 & 806.3 & 0.42 & 49.2 & 0.25 & 49.1 \\
\hline & $\mathrm{RCP} 4.5$ & 10.8 & 791.0 & 0.43 & 52.3 & 0.27 & 49.7 \\
\hline & RCP8.5 & 10.8 & 808.4 & 0.43 & 52.0 & 0.26 & 49.2 \\
\hline \multirow[t]{3}{*}{ Mid (2046-2065) } & RCP2.6 & 11.1 & 816.4 & 0.42 & 56.4 & 0.20 & 50.7 \\
\hline & RCP4.5 & 11.5 & 820.3 & 0.54 & 59.9 & 0.27 & 46.5 \\
\hline & RCP8.5 & 12.0 & 827.1 & 0.51 & 67.2 & 0.33 & 49.9 \\
\hline \multirow[t]{3}{*}{ Late (2076-2095) } & RCP2.6 & 11.1 & 813.6 & 0.52 & 54.5 & 0.24 & 55.6 \\
\hline & $\mathrm{RCP} 4.5$ & 11.9 & 831.1 & 0.55 & 62.2 & 0.24 & 52.7 \\
\hline & RCP8.5 & 13.4 & 868.9 & 0.72 & 83.2 & 0.32 & 57.7 \\
\hline
\end{tabular}

AOGCMs. For average annual precipitation values, the standard deviations among AOGCMs were slightly higher than interannual variations. These results were mainly due to the consideration of an ensemble of AOGCMs that has an effect of reducing interannual variations compared to interannual variations from individual AOGCMs (Knutti et al., 2010). Therefore, one should take into account these effects in using ensembles of AOGCM results for impact analysis. Moreover, variations among AOGCMs may indicate that the choice of models within an ensemble for climate change impact analysis may result in different conclusions.

\subsection{Streamflow $(Q)$}

The historical (1991 to 2010) annual average $Q$ at the watershed outlet was about $212 \mathrm{~mm}\left(63 \mathrm{~m}^{3} \mathrm{~s}^{-1}\right)$. There were both predicted decreases (1 to $24 \%$ ) and increases ( 3 to $75 \%$ ) in $Q$ for the BL, AC and PC agricultural scenarios in response to the different climate projections (Fig. $4 \mathrm{a}-\mathrm{c}$ ), relative to the historical average $Q$. For the PS and AS scenarios, however, there were decreases (15 to $83 \%$ ) in $Q$ for all but one of the climate projections (Fig. 4a-c). Despite decreases in precipitation and increases in temperature, an increase in $Q$ in some of the scenarios indicates the possible occurrence of larger and more frequent high intensity precipitation events than the historical-observed values in the projected climate data (Schoof, 2015; Kharin and Zwiers, 2000). Moreover, a reduction in ET (evapotranspiration) due to increased $\mathrm{CO}_{2}$ levels, especially in the mid- and late century periods, also contributed to simulated increases in streamflow in mid- and late century scenarios similar to results reported by Jha et al. (2006) and Wu et al. (2012).

The PS and AS scenarios resulted in lower estimated $Q$ compared to the other scenarios and the historical baseline, for a given climate scenario, while very small difference were observed between the BL, AC and PC scenarios (Fig. 4a-c). The AS agricultural scenario exhibited the highest decrease in streamflow (or water yield) as expected. Similar results were indicated by previous studies (e.g., Kim et al., 2013; Parajuli and Duffy, 2013; Schilling et al., 2008; Wu et al., 2013). This reveals that large-scale conversion to switchgrass could result in reduced water availability due to increased ET and conversely reduced $Q$, which could render it less desirable as a climate change adaptation strategy in the watershed for future climate conditions that manifest lower precipitation levels. Also, as noted previously, the AC and AS scenarios reflect agricultural production schemes that are consistent with the high GHG emission RCP8.5 pathway and the low emission RCP2.6 pathway, respectively. A comparison on this basis reveals that the AS scenario resulted in a much higher reduction in $Q$ compared to the AC scenario, relative to the previous comparison (Fig. 4a-c), which further underscores that widespread adoption of just switchgrass in current intensively cropped Corn Belt watersheds may not be a viable strategy in mitigating climate change impacts on water availability.

Comparisons were also made between climatic projections for a given agricultural scenario. The results show a decrease in $Q$ relative to historical-observed values for early century under all RCPs (Fig. 4a). At mid-century, decreases in $Q$ were predicted for the majority of agricultural scenarioclimate projection combinations, except for the $\mathrm{BL}, \mathrm{AC}$ and PC scenarios in response to the projected RCP8.5 pathway. However, there was a consistent increase in $Q$, during the late century time period, across agricultural scenarios in response to the RCP8.5 projection and for the BL, AC and PC scenarios when impacted by the RCP4.5 projection (Fig. 4ac). These increases in $Q$ from early-to-late century could be attributed to the precipitation increase in the same manner as discussed in Sect. 4.1. Except for the early century time pe- 


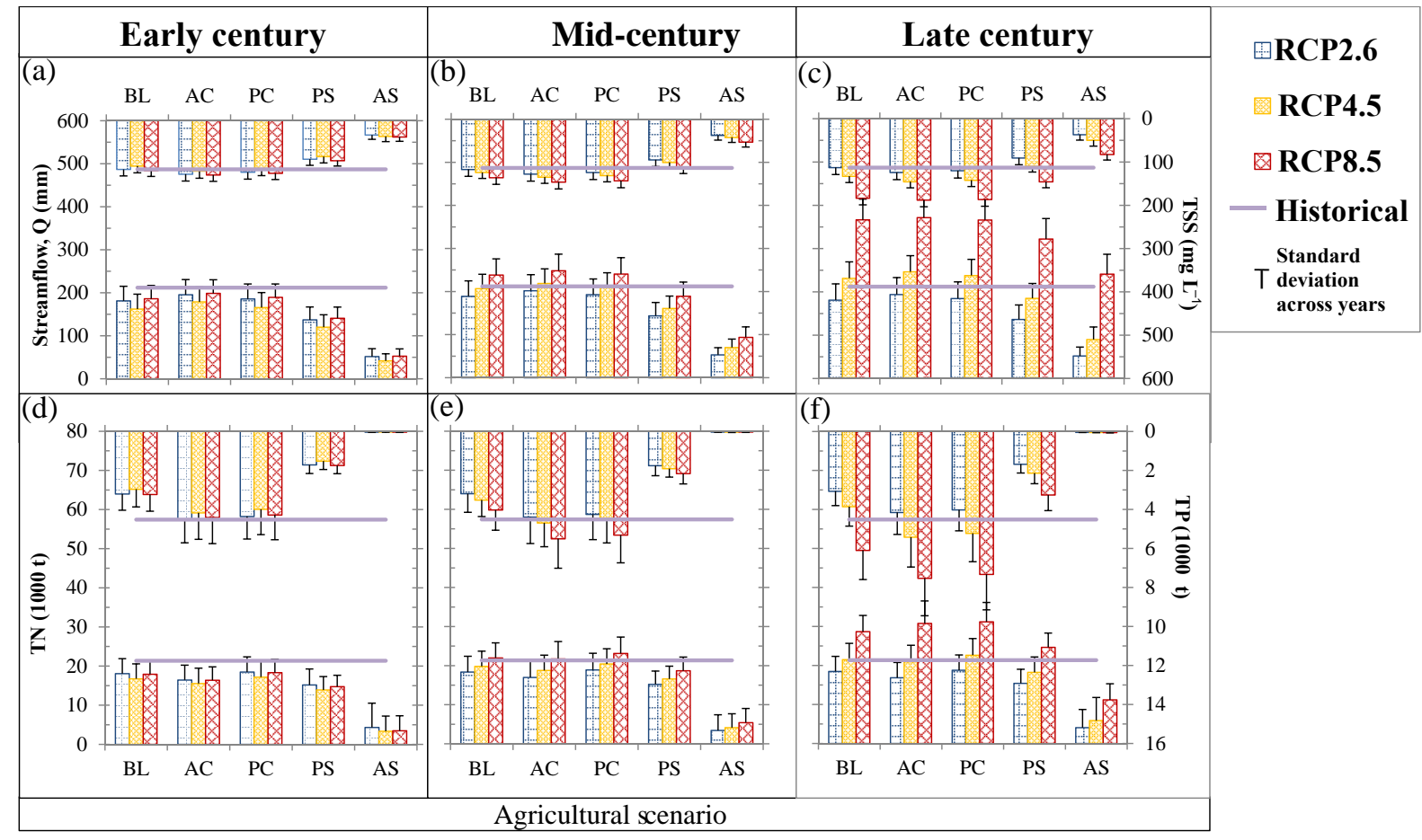

Figure 4. Streamflow $(Q)$, total suspended solid (TSS), total nitrogen (TN) and total phosphorous (TP) results at the outlet of the watershed in different agricultural and climate scenarios.

riod, $Q$ increased from RCP2.6 to RCP8.5 for all agricultural scenarios. The maximum increases $(\leq 75 \%$ of historical $Q$ ) were simulated under the late century RCP 8.5 for all agricultural scenarios.

Previously, Jha and Gassman (2014) used an ensemble of GCMs projections, developed within the framework of CMIP Phase 3 (CMIP3; PCMDI, 2016), to simulate the impacts of projected future climate change on the RRW with SWAT. They concluded that there was an overall average decrease in total $Q$ of $17 \%$ in the mid-century period, compared to $Q$ for the years 1961 to 2000. Similar BL scenario results were obtained in this study for the RCP2.6 projections (14.7, 11.0 and $14.7 \%$ for the early, mid- and late 21 st century, respectively) and RCP4.5 and RCP8.5 early century projections (23.7 and $12.4 \%$, respectively). The mid-century RCP4.5 scenarios showed a slight decrease $(2.6 \%)$ in $Q$, whereas increases in $Q$ were simulated for the RCP8.5 scenario in both the mid- and late century (12.3 and $72.6 \%$, respectively), and for the late century RCP4.5 scenario (9\%).

The standard deviations of annual $Q$ between AOGCMs and future time periods (Fig. 4 and Tables A1 and A2) followed trends similar to the temperature and precipitation results discussed in Sect. 4.1. The standard deviation across time periods for the historical period was greater than for any of the future temporal periods for all of the agricultural scenarios. Similarly, the standard deviation between AOGCMs is greater than that across future time periods. These trends are also similar for all TSS, TN and TP values (Fig. 4 and Tables A1 and A2).

\subsection{Total suspended sediment (TSS)}

Simulated TSS impacts for the different agricultural scenario-climate projection combinations were compared to each other and vs. the simulated historical TSS values. The historical (1991-2010) annual average TSS concentration at the watershed outlet was about $113 \mathrm{mg} \mathrm{L}^{-1}\left(2.25 \times 10^{5} \mathrm{t}\right)$. Compared to the historical TSS concentration, there were increases in TSS for the AC and PC scenarios across all climate projections, decreases for the PS scenario for most of the climate projections and decreases for AS in all three climate projections (Fig. 4d-f). The increases in TSS were the highest for the AC $(\leq 67 \%)$ scenario, followed by the PC $(\leq 65 \%)$ and BL $(\leq 63 \%)$ scenarios. Peak TSS decreases were 74 and $27 \%$ for the AS and PS scenarios, respectively.

For a given climate scenario, there were $1.6-7.1 \%$ increases in TSS for PC and 2.3-11.1\% increases for AC compared to the BL scenario. This indicates how intensively the RRW is utilized for agricultural production already. It was only when switchgrass was introduced (AS and PS scenarios) that significant decreases in TSS were observed (18-27\% for PS and $56-74 \%$ for AS) relative to the BL scenario. Hence, switchgrass seems to be a good adaptation strategy with respect to addressing TSS reductions. This result is magnified when results are assessed based on agricultural scenar- 
ios simulated with the appropriate climate scenarios, as discussed in "Streamflow $(Q)$ " section. Generally, the predicted TSS values followed the $Q$ trends for all of the climate projection and agricultural scenario categories (Fig. 4d-f). For a given agricultural scenario, TSS increased continuously from the early-to-late 21 st century. Considerable reduction in TSS was simulated in the AS agricultural scenario under all climate scenarios compared to historical levels. However, the AS scenario must be viewed as extreme and impractical, due to the importance of corn as a crop in the RRW and Corn Belt region in general. However, the PS agricultural scenario, which is a more plausible scenario, may require additional best-management practices to significantly reduce TSS yield and transport from the watershed.

\subsection{Total phosphorous (TP)}

The annual average historical-simulated (1991 to 2010) $\mathrm{TP}$ at the watershed outlet was roughly $4.52 \times 10^{3} \mathrm{t}$ (or $7.6 \mathrm{mg} \mathrm{L}^{-1}$ ). Comparisons were made between the different scenario results, and between historical and scenario results. Due mainly to the absence of phosphorus fertilizer application and reduction in surface runoff when planting switchgrass, there were significant reductions in TP in the PS and AS agricultural scenarios compared to historical-simulated values (up to 66 and 99\%, respectively) and BL scenario (up to 49 and $99 \%$, respectively) (Fig. 4d-f). The differences in tillage practices between agricultural scenarios also contributed to the difference in TP output among scenarios, due to the shifts in tillage practices used in the BL scenario vs. just conventional tillage for $\mathrm{CC}$ in the $\mathrm{PC}$ and $\mathrm{AC}$ scenarios, and elimination of tillage for the PS and AS scenarios. Conventional tillage practices result in higher sediment and phosphorus yields but conservation and no-till tillage practices can result in lower yields under some conditions. Various researchers (e.g., Parajuli et al., 2013; Tomer et al., 2008; Andraski et al., 2003; Bundy et al., 2001) have demonstrated similar effects of tillage practices on sediment and/or phosphorous outputs from agricultural fields.

For a given climate scenario, the PS and AS scenarios exhibited similar reductions in TP output $(\leq 49$ and $99 \%$, respectively) compared to the BL scenario. Both of the CCbased scenarios (PC and $\mathrm{AC}$ ) resulted in large increases in $\mathrm{TP}$, compared to both the BL scenario for all climate projections ( $\leq 36$ and $41 \%$ for $\mathrm{PC}$ and $\mathrm{AC}$, respectively) and historical simulated values ( $\leq 62$ and $67 \%$ for $\mathrm{PC}$ and $\mathrm{AC}$, respectively).

\subsection{Total nitrogen (TN)}

The annual average historical-simulated (1991 to 2010) TN load value at the watershed outlet was about $2.14 \times 10^{4} \mathrm{t}$ (or $36 \mathrm{~m} \mathrm{~L}^{-1}$ ). Comparisons were made between simulated historical and scenario annual average $\mathrm{TN}$ load values at the watershed outlet, and also among scenarios. These compar- isons reveal two important insights: (1) the AC scenario resulted in lower TN loads relative to the BL scenario, which was not originally expected, and (2) the PC scenario resulted in the highest TN loads of all of the agricultural scenarios (Fig. 4a-c). This implies that, with respect to TN output, the current agricultural management conditions (BL scenario) in the RRW are already extremely intensive, and are comparable to planting continuous corn everywhere with conventional tillage and $202 \mathrm{~N} \mathrm{~kg} \mathrm{ha}^{-1}$ of fertilizer (AC scenario). Even though the fertilizer application rates were less than $202 \mathrm{~N} \mathrm{~kg} \mathrm{ha}^{-1}$ in the BL scenario, manure was applied in addition to the fertilizer (Teshager et al., 2015). This resulted in a slightly higher TN load for the BL scenario. However, as previously described, the PC scenario reflects a combination of BL scenario cropping system and management practices, and conversion of some land parcels to $\mathrm{CC}$, resulting in slightly higher TN loads as compared to both the BL and AC scenarios. Also, the introduction of switchgrass in the RRW AS and PS scenarios has the potential to reduce the total nitrogen outflow from the watershed significantly relative to historical levels ( $\leq 84 \%$ for AS and $\leq 35 \%$ for PS) as shown in Fig. $4 \mathrm{a}-\mathrm{c}$. For a given climate projection, annual average TN loads were reduced by to $81 \%$ for AS and $18 \%$ for the PS scenarios in comparison to the BL scenario. This was due to both the elimination of tillage in switchgrass cropping systems and the capability of switchgrass to scavenge nitrate from the soil-water matrix. Planting switchgrass in select areas of a watershed, similar to the PS scenario approach, and implementing effective best-management practices could further reduce nitrogen losses to Corn Belt stream systems. The effects of expanded adoption of switchgrass depicted in the PS and AS scenarios on reductions in TN loads are further magnified when examining the results within the context of the RCP4.5 and RCP2.6 pathways, which were previously identified as the two respective pathways that the PS and AS scenarios were most correlated with, especially for the late century time period. Similar to the $Q$ and TSS results, the TN loads increased from the early part of the century to the late part of the century, especially for the RCP4.5 and RCP8.5 pathways (Fig. $4 \mathrm{a}-\mathrm{c}$ ).

\subsection{Crop yields}

Crop yield analyses were done to point out the potential impacts of climate change on corn and switchgrass yields, assuming that the current production technologies for both crops remain the same, based on crop yield estimates obtained from the AC and AS scenarios. The 20-year (1991 to 2010) historical-simulated average yields across the entire RRW was $10 \mathrm{tha}^{-1}$ for corn and $15.5 \mathrm{tha}^{-1}$ for switchgrass. The AC scenario corn yields and AS scenario switchgrass yields were predicted to decline across future climate conditions, as compared to the historical-simulated yields, especially during the mid- and late centuries for the higher RCP4.5 and RCP8.5 GHG emission pathways (Fig. 5). 


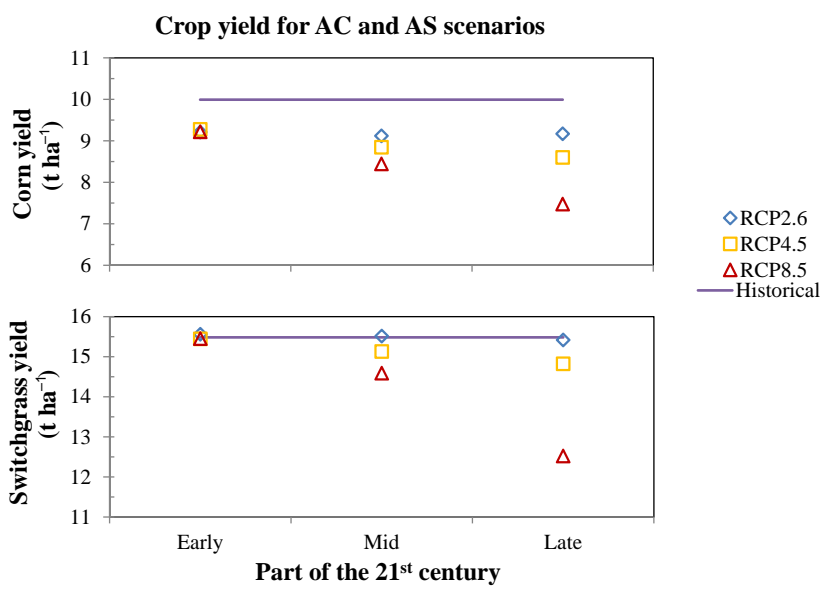

Figure 5. Watershed average crop yield for corn and switchgrass using all corn (AC) and all switchgrass (AS) agricultural scenarios, respectively.

The reduction in corn yields ranged from $7 \%$ during the early century time period to $25 \%$ in the late century time period (Fig. 5). However, no reductions were predicted for switchgrass yields initially in the early century, but estimated declines in switchgrass yields of $\leq 19 \%$ occurred in the latter part of the century. In the early century, the effects of the emission pathways on the crop yields were insignificant; however, the emission pathway effects became more pronounced in the mid- and late century simulations (Fig. 5). There were essentially no differences in corn or switchgrass yields between the early, mid- and late century time period simulations for the low emission RCP2.6 pathway. The highest yield reductions, $25 \%$ for corn and $19 \%$ for switchgrass, were simulated in response to the high emission RCP8.5 pathway at the end of the century. Lower percentage crop yield reductions were found in this study compared to similar previous research results (e.g., Miao et al., 2015; Ummenhofer et al., 2015; Cai et al., 2009; Schlenker and Roberts, 2008). One possible reason that lower reductions in crop yields were predicted within this study could be the inclusion of $\mathrm{CO}_{2}$ concentrations during the simulations, and the capability of SWAT to account for positive effects of $\mathrm{CO}_{2}$ concentration on crop yield. In addition, higher precipitation amounts that characterize the RCP8.5 pathway late century time period could have partly offset the effects of increased temperatures on yield. However, the predicted corn and switchgrass yields for the RCP8.5 pathway late century time period were lower than other time periods, even though the average annual precipitation was higher than the historical or any other future projected precipitation. This result is consistent with the results presented in Sect. 4.2 because the increase in annual precipitation was due mainly to more high intensity daily precipitation events (Schoof, 2015), which will not necessarily be beneficial for crop growth.

\section{Conclusions and recommendations}

The SWAT simulation results representing five agricultural scenarios, eight AOGCMs, three representative concentration pathways (RCP2.6, RCP4.5 and RCP8.5) and three 20year temporal blocks (early, mid-, and late 21 st centuries) were systematically aggregated to analyze the combined impacts of agricultural scenario and climate change on water, total suspended solids, total nitrogen and total phosphorous yields at the Raccoon River watershed outlet. Moreover, the effects of climate change on corn and switchgrass yields were assessed by analyzing the results of the AC and AS scenarios.

In general, the results indicated the need for developing alternative biofuel cropping systems to counteract future problems that could develop from relying on intensification of corn production in Corn Belt region watersheds to mitigate potential future water quality problems. The results of this study were consistent with the findings of Wilson and Weng (2011), where future climate change would exert a larger impact on the concentration of pollutants than the potential impact of land use (Fig. 4a-f). The results also showed that significant reduction in water pollution could be accomplished by expanded planting of switchgrass in the RRW as depicted by the PS and AS scenarios. Even though it provides the best results in alleviating water quality problems in the future, the promising future water quality benefits suggested by the AS scenario results are unrealistic due to the need for production of corn or other crops. Planting more switchgrass could reduce row crop (especially corn) production in the region significantly. However, if biofuels from switchgrass become commercially viable, cellulosic biofuel production could reduce the pressure on the need for corn and make planting more switchgrass feasible. There were, however, scenarios where results indicated reductions in water quality in PS relative to the BL historical simulation. This shows that planting switchgrass alone may not be sufficient to improve water quality for heavily tile agricultural watersheds like the RRW. Therefore, our results indicate that substantially improving water quality will require a combination of working land practices (such as conservation tillage and cover crops) and land retirement/perennial plantings (such as planting grasses such as switchgrass). This will in turn necessitate substantive conservation efforts, higher than historical levels. Unfortunately, the latest farm bill has both reduced overall conservation funding by almost EUR 4 billion over a 10 year span and reduced the proportion of funding going to land retirement (Stubbs, 2014). Therefore, increased conservation will only occur via novel public-private partnerships or through regulatory drivers.

It is also important to consider how the agricultural scenarios modeled for the RRW fit with the forcing scenarios, and with the larger context of agricultural adaptation to climate change at a global scale. Specifically, the AS and PS scenarios would be compatible with the RCP2.6 pathway if coupled with sustainable intensification of agricultural practices and 
advanced biofuel production (Melillo et al., 2009; Tilman et al., 2011; Foley et al., 2011). Otherwise, the reduction in corn production from areas such as the RRW would result in more environmental degradation, deforestation and higher carbon emissions elsewhere. Conversely, it is possible - though not likely - that the AS and PS scenarios could occur in a high emission world, if strong conservation measures were to be limited to the US. Similarly, the AC scenario might be compatible with the low emission RCP2.6 pathway if effective conservation measures to reduce deforestation were implemented at a global scale, although US conservation policies lag behind. This illustrates the importance of the interplay of national and global conservation policies in addressing the challenge of climate change. In general, in order to promote local water quality in heavily farmed watersheds such as the $\mathrm{RRW}$, as well as reducing global GHG emissions, more complex landscapes and serious conservation measures will have to be put into practice across the planet.

Therefore, future work will focus on using the different climate scenarios to assess how implementing bestmanagement practices, such as cover crops, less intensive tillage practices, fertilizer application timing and amount, filter strips, etc., in addition to planting switchgrass partially on selected lands, performs in reducing water pollution from agricultural lands. Moreover, monthly analysis, similar to that of Jha et al. (2006) and Jha and Gassman (2014), could reveal additional results more relevant for water resources in watersheds like the RRW, where the river is utilized for municipal and industrial water supply purposes.
We should also point out that model parameters used during calibration and validation periods were kept the same for our future scenario simulations. This assumption could carry more model parameter uncertainties in scenario simulations depending on the extent of future technological and climate changes. For example, in the last century there have been large changes to the technologies used in agriculture - from synthetic fertilizers to new hybrids to precision agriculture. If such considerable changes were to continue, the impacts on water quality could be significant. This is even more important if we consider how likely it is that agriculture will develop technologies to adapt to climate change. Hence, future studies should devise a way to take these potential effects into account when parametrizing SWAT modeling for future scenario analysis.

\section{Data availability}

All underlying data for this research work are available from the authors upon request. Organizing and presenting the complete data set used in this study for the general public to easily access it, however, requires significant additional work. Hence we are currently planning to archive the entire data for future research work and accessibility. 
Appendix A

Table A1. Standard deviation of $Q$, TSS, TN and TP among 8 climate models.

\begin{tabular}{|c|c|c|c|c|c|c|c|c|c|c|}
\hline & \multirow[t]{2}{*}{ LULC } & \multicolumn{3}{|c|}{ Early } & \multicolumn{3}{|c|}{ Mid } & \multicolumn{3}{|c|}{ Late } \\
\hline & & RCP2.6 & RCP4.5 & RCP8.5 & $\mathrm{RCP} 2.6$ & RCP4.5 & RCP8.5 & $\mathrm{RCP} 2.6$ & RCP4.5 & RCP8.5 \\
\hline \multirow[t]{5}{*}{ Flow, $Q(\mathrm{~mm})$} & BL & 37.70 & 36.46 & 35.79 & 42.06 & 55.28 & 53.16 & 40.79 & 59.33 & 81.05 \\
\hline & $\mathrm{AC}$ & 38.10 & 38.90 & 36.60 & 43.13 & 55.04 & 52.94 & 41.71 & 55.14 & 81.54 \\
\hline & PC & 37.91 & 36.60 & 36.14 & 42.28 & 55.23 & 53.23 & 41.22 & 55.77 & 81.99 \\
\hline & PS & 34.18 & 30.50 & 31.34 & 38.00 & 50.60 & 49.41 & 35.91 & 53.38 & 84.09 \\
\hline & AS & 27.05 & 19.30 & 21.43 & 28.57 & 45.45 & 42.59 & 26.74 & 48.35 & 87.64 \\
\hline \multirow[t]{5}{*}{$\mathrm{TSS}\left(\mathrm{mg} \mathrm{L}^{-1}\right)$} & BL & 16.35 & 16.58 & 15.94 & 18.33 & 22.21 & 20.38 & 17.70 & 22.50 & 24.52 \\
\hline & $\mathrm{AC}$ & 16.73 & 17.69 & 16.73 & 18.18 & 20.53 & 26.23 & 18.67 & 23.14 & 21.47 \\
\hline & $\mathrm{PC}$ & 17.22 & 17.51 & 16.90 & 18.84 & 23.80 & 22.00 & 18.62 & 21.20 & 26.36 \\
\hline & PS & 15.33 & 15.62 & 15.35 & 18.24 & 19.96 & 19.34 & 17.04 & 18.72 & 21.21 \\
\hline & AS & 10.72 & 12.85 & 12.19 & 15.13 & 15.84 & 14.67 & 13.51 & 15.96 & 18.20 \\
\hline \multirow[t]{5}{*}{$\mathrm{TN}(1000 \mathrm{t})$} & $\mathrm{BL}$ & 3.76 & 3.93 & 3.53 & 4.48 & 4.28 & 4.16 & 3.56 & 5.06 & 6.05 \\
\hline & $\mathrm{AC}$ & 3.79 & 4.01 & 3.49 & 4.54 & 4.62 & 5.02 & 3.84 & 5.56 & 9.69 \\
\hline & PC & 3.89 & 4.11 & 3.58 & 4.74 & 4.59 & 4.71 & 3.77 & 5.42 & 7.88 \\
\hline & PS & 3.60 & 3.47 & 3.10 & 3.76 & 3.61 & 3.69 & 3.21 & 4.48 & 5.56 \\
\hline & AS & 2.97 & 2.99 & 2.82 & 2.83 & 2.82 & 3.50 & 3.22 & 4.13 & 5.14 \\
\hline \multirow[t]{5}{*}{$\mathrm{TP}(1000 \mathrm{t})$} & BL & 0.83 & 0.82 & 0.85 & 1.02 & 0.98 & 1.03 & 0.72 & 1.20 & 1.88 \\
\hline & $\mathrm{AC}$ & 1.22 & 1.23 & 1.25 & 1.45 & 1.40 & 1.50 & 1.09 & 1.73 & 2.52 \\
\hline & PC & 1.19 & 1.17 & 1.19 & 1.39 & 1.35 & 1.43 & 1.05 & 1.64 & 2.36 \\
\hline & PS & 0.41 & 0.42 & 0.45 & 0.56 & 0.52 & 0.53 & 0.44 & 0.62 & 1.14 \\
\hline & AS & 0.016 & 0.011 & 0.015 & 0.015 & 0.023 & 0.016 & 0.013 & 0.022 & 0.025 \\
\hline
\end{tabular}

Table A2. Standard deviation of $Q$, TSS, TN and TP across years (in each 20-year block).

\begin{tabular}{|c|c|c|c|c|c|c|c|c|c|c|c|}
\hline & \multirow[t]{2}{*}{ LULC } & \multicolumn{3}{|c|}{ Early } & \multicolumn{3}{|c|}{ Mid } & \multicolumn{3}{|c|}{ Late } & \multirow[t]{2}{*}{ Historica } \\
\hline & & RCP2.6 & RCP4.5 & $\mathrm{RCP} 8.5$ & RCP2.6 & RCP4.5 & RCP8.5 & $\mathrm{RCP} 2.6$ & RCP4.5 & RCP8.5 & \\
\hline \multirow[t]{5}{*}{ Flow, $Q(\mathrm{~mm})$} & $\mathrm{BL}$ & 33.97 & 34.58 & 30.88 & 35.89 & 33.24 & 37.45 & 37.54 & 37.87 & 47.76 & \multirow[t]{5}{*}{107.50} \\
\hline & $\mathrm{AC}$ & 35.30 & 35.54 & 31.69 & 37.24 & 33.83 & 38.26 & 39.02 & 37.20 & 48.22 & \\
\hline & $\mathrm{PC}$ & 34.82 & 34.83 & 31.13 & 36.39 & 33.36 & 37.84 & 38.41 & 37.16 & 48.03 & \\
\hline & PS & 29.95 & 28.71 & 25.98 & 30.78 & 28.70 & 32.76 & 33.31 & 34.32 & 47.20 & \\
\hline & AS & 18.36 & 16.40 & 17.02 & 16.33 & 19.50 & 24.15 & 20.48 & 28.85 & 45.75 & \\
\hline \multirow[t]{5}{*}{$\mathrm{TSS}\left(\mathrm{mg} \mathrm{L}^{-1}\right)$} & $\mathrm{BL}$ & 15.05 & 15.68 & 13.70 & 16.05 & 13.78 & 15.42 & 16.04 & 14.67 & 15.41 & \multirow[t]{5}{*}{34.1} \\
\hline & $\mathrm{AC}$ & 15.72 & 16.42 & 14.47 & 16.49 & 14.32 & 15.97 & 16.72 & 14.12 & 15.55 & \\
\hline & $\mathrm{PC}$ & 15.97 & 16.67 & 14.51 & 16.64 & 14.43 & 16.13 & 17.05 & 14.36 & 15.64 & \\
\hline & PS & 14.24 & 14.45 & 12.52 & 15.47 & 12.72 & 14.38 & 15.83 & 13.30 & 13.89 & \\
\hline & AS & 9.99 & 12.15 & 10.00 & 11.18 & 11.54 & 11.74 & 12.69 & 13.66 & 12.87 & \\
\hline \multirow[t]{5}{*}{$\mathrm{TN}(1000 \mathrm{t})$} & $\mathrm{BL}$ & 3.84 & 3.83 & 3.36 & 4.03 & 3.89 & 3.84 & 3.89 & 4.15 & 4.15 & \multirow[t]{5}{*}{14.47} \\
\hline & $\mathrm{AC}$ & 3.79 & 3.93 & 3.43 & 4.13 & 3.92 & 4.44 & 3.92 & 4.25 & 5.76 & \\
\hline & $\mathrm{PC}$ & 3.88 & 4.01 & 3.46 & 4.27 & 3.89 & 4.20 & 3.94 & 4.26 & 4.95 & \\
\hline & PS & 4.07 & 3.41 & 2.92 & 3.41 & 3.28 & 3.51 & 3.63 & 3.94 & 3.66 & \\
\hline & AS & 6.21 & 3.88 & 3.82 & 4.01 & 3.55 & 3.62 & 4.66 & 5.93 & 4.13 & \\
\hline \multirow[t]{5}{*}{$\mathrm{TP}(1000 \mathrm{t})$} & $\mathrm{BL}$ & 0.83 & 0.90 & 0.86 & 0.95 & 0.84 & 1.04 & 0.74 & 1.00 & 1.49 & \multirow[t]{5}{*}{3.05} \\
\hline & $\mathrm{AC}$ & 1.20 & 1.35 & 1.34 & 1.35 & 1.22 & 1.51 & 1.13 & 1.53 & 1.92 & \\
\hline & $\mathrm{PC}$ & 1.15 & 1.29 & 1.27 & 1.29 & 1.16 & 1.42 & 1.07 & 1.45 & 1.82 & \\
\hline & PS & 0.44 & 0.43 & 0.42 & 0.51 & 0.43 & 0.53 & 0.45 & 0.54 & 0.80 & \\
\hline & AS & 0.012 & 0.011 & 0.012 & 0.011 & 0.016 & 0.013 & 0.010 & 0.015 & 0.015 & \\
\hline
\end{tabular}


Acknowledgements. This material is based upon work supported by the National Science Foundation under grant no. 1009925. Any opinions, findings and conclusions or recommendations expressed in this material are those of the authors and do not necessarily reflect the views of the National Science Foundation.

Edited by: D. Yang

Reviewed by: two anonymous referees

\section{References}

Agren, M. M.: Raccoon River Water Quality Master Plan. Prepared on behalf of the M\&M Divide Resource Conservation \& Development, available at: http://www.iowadnr.gov/Portals/idnr/ uploads/water/watershed/files/raccoonmasterwmp13.PDF (last access: 24 July 2015), 2011.

Andraski, T. W., Bundy, L. G., and Kilian, K. C.: Manure history and long-term tillage effects on soil properties and phosphorus losses in runoff, J. Environ. Qual., 32, 1782-1789, 2003.

Arnold, J. G., Srinivasan, R., Muttiah, R. S., and Williams, J. R.: Large area hydrologic modeling and assessment part I: Model development, J. Am. Water Resour. As., 34, 73-89, doi:10.1111/j.1752-1688.1998.tb05961.x, 1998.

Arnold, J. G., Allen, P. M., Volk, M., Williams, J. R., and Bosch, D. D.: Assessment of different representations of spatial variability on SWAT model performance, T. ASABE, 53, 1433-1443, doi:10.13031/2013.34913, 2010.

Arnold, J. G., Kiniry, J. R., Srinivasan, R., Williams, J. R., Haney, S. L., and Neitsch, S. L.: Soil and Water Assessment Tool Input/Output Documentation, Version 2012, Texas Water Resources Institute, Temple, TX, USA, TR-439, 2012.

Bressiani, D. D. A., Gassman, P. W., Fernandes, J. G., Garbossa, L. H. P., Srinivasan, R., Bonumá, N. B., and Mendiondo, E. M.: A review of Soil and Water Assessment Tool (SWAT) applications in Brazil: Challenges and Prospects, Int. J. Agric. Biol. Eng., 8, 9-35, doi:10.3965/j.ijabe.20150803.1765, 2015.

Bundy, L. G., Andraski, T. W., and Powell, J. M.: Management practice effects on phosphorus losses in runoff in corn production systems, J. Environ. Qual., 30, 1822-1828, 2001.

Cai, X., Wang, D., and Laurent, R.: Impact of Climate Change on Crop Yield: A Case Study of Rainfed Corn in Central Illinois, J. Appl. Meteorol. Clim., 48, 1868-1881, doi:10.1175/2009JAMC1880.1, 2009.

CARD: SWAT literature database for peer-reviewed journal articles. Center for Agricultural and Rural Development, Iowa State University, Ames, Iowa, available at: https://www.card.iastate.edu/ swat_articles/ (last access: 11 January 2016), 2016.

Chapman, W. L. and Walsh, J. E.: Simulations of Arctic Temperature and Pressure by Global Coupled Models, J. Climate, 20, 609-632, doi:10.1175/JCLI4026.1, 2007.

Chien, H., Yeh, P. J.-F., and Knouft, J. H.: Modeling the potential impacts of climate change on streamflow in agricultural watersheds of the Midwestern United States, J. Hydrol., 491, 73-88, doi:10.1016/j.jhydrol.2013.03.026, 2013.

Chylek, P., Li, J., Dubey, M. K., Wang, M., and Lesins, G.: Observed and model simulated 20th century Arctic temperature variability: Canadian Earth System Model CanESM2, Atmos.
Chem. Phys. Discuss., 11, 22893-22907, doi:10.5194/acpd-1122893-2011, 2011.

Davis, S. C., Parton, W. J., Grosso, S. J. D., Keough, C., Marx, E., Adler, P. R., and DeLucia, E. H.: Impact of second-generation biofuel agriculture on greenhouse-gas emissions in the corngrowing regions of the US, Front. Ecol. Environ., 10, 69-74, doi:10.1890/110003, 2012.

DMWW: Fact sheet: Nitrate Removal Facility, Des Moines Water Works, available at: http://www.dmww.com/upl/documents/ water-quality/lab-reports/fact-sheets/nitrate-removal-facility. pdf (last access: 20 January 2016), 2015.

Donner, S. D. and Kucharik, C. J.: Corn-based ethanol production compromises goal of reducing nitrogen export by the Mississippi River, P. Natl. Acad. Sci. USA, 105, 4513-4518, doi:10.1073/pnas.0708300105, 2008.

Dreborg, K. H.: Scenarios and structural uncertainty. Explorations in the field of sustainable transport, Doctoral Thesis, Royal Institute of Technology, Stockholm, 2004.

Duffy, M.: Estimated Costs for Production, Storage and Transportation of Switchgrass, Iowa State University Extension, File A1-22, 2008.

Duffy, M: Estimated Costs of Crop Production in Iowa - 2013 FM1712, Iowa State University Extension, 2013.

Dufresne, J.-L., Foujols, M.-A., Denvil, S., Caubel, A., Marti, O., Aumont, O., and Balkanski, Y., Balkanski, Y., Bekki, S., Bellenger, H., Benshila, R., Bony, S., Bopp, L., Braconnot, P., Brockmann, P., Cadule, P., Cheruy, F., Codron, F., Cozic, A., Cugnet, D., de Noblet, N., Duvel, J.-P., Ethé, C., Fairhead, L., Fichefet, T., Flavoni, S., Friedlingstein, P., Grandpeix, J.-Y., Guez, L., Guilyardi, E., Hauglustaine, D., Hourdin, F., Idelkadi, A., Ghattas, J., Joussaume, S., Kageyama, M., Krinner, G., Labetoulle, S., Lahellec, A., Lefebvre, M.-P., Lefevre, F., Levy, C., Li, Z. X., Lloyd, J., Lott, F., Madec, G., Mancip, M., Marchand, M., Masson, S., Meurdesoif, Y., Mignot, J., Musat, I., Parouty, S., Polcher, J., Rio, C., Schulz, M., Swingedouw, D., Szopa, S., Talandier, C., Terray, P., Viovy, N., and Vuichard, N.: Climate Change Projections Using the IPSL-CM5 Earth System Model: From CMIP3 to CMIP5, Clim. Dynam., 40, 2123-2165, doi:10.1007/s00382-012-1636-1, 2013.

Duku, C., Rathjens, H., Zwart, S. J., and Hein, L.: Towards ecosystem accounting: a comprehensive approach to modelling multiple hydrological ecosystem services, Hydrol. Earth Syst. Sci., 19, 4377-4396, doi:10.5194/hess-19-4377-2015, 2015.

ENERGY.GOV: Largest Cellulosic Ethanol Plant in the World Opens October 30. Department of Energy, Office of Energy Efficiency \& Renewable Energy, Washington, D.C., available at: http://energy.gov/eere/bioenergy/articles/ largest-cellulosic-ethanol-plant-world-opens-october-30, last access: 16 December 2015.

Ficklin, D. L., Luo, Y., Luedeling, E., and Zhang, M.: Climate Change Sensitivity Assessment of a Highly Agricultural Watershed Using SWAT, J. Hydrol., 374, 16-29, doi:10.1016/j.jhydrol.2009.05.016, 2009.

Ficklin, D. L., Stewart, I. T., and Maurer, E. P.: Effects of projected climate change on the hydrology in the Mono Lake Basin, California, Climatic Change, 116, 111-131, doi:10.1007/s10584012-0566-6, 2013.

Foley, J. A., Ramankutty, N., Brauman, K. A., Cassidy, E. S., Gerber, J. S., Johnston, M., Mueller, N. D., O’Connell, C., Ray, D. 
K., West, P. C., Balzer, C., Bennett, E. M., Carpenter, S. R., Hill, J., Monfreda, C., Polasky, S., Rockstrom, J., Sheehan, J., Siebert, S., Tilman, D., and Zaks, D. P. M.: Solutions for a cultivated planet, Nature, 478, 337-342, doi:10.1038/nature10452, 2011.

Gassman, P. W. and Wang, Y. K.: IJABE SWAT Special Issue: Innovative modeling solutions for water resource problems, Int. J. Agric. Biol. Eng., 8, 1-8, doi:10.3965/j.ijabe.20150803.1763, 2015.

Gassman, P. W., Reyes, M., Green, C. H., and Arnold, J. G.: The Soil and Water Assessment Tool: Historical development, applications, and future directions, T. ASABE, 50, 1211-1250, doi:10.13031/2013.23634, 2007.

Gassman, P. W., Balmer, C., Siemers, M., and Srinivasan, R.: The SWAT Literature Database: Overview of database structure and key SWAT literature trends. Proceedings of the 2014 International SWAT Conference, July 28-1 August, Pernambuco, Brazil, Texas Water Resources Institute Technical Report - TR472, available at: http://swat.tamu.edu/conferences/2014/ (last access: 19 January 2016), 2014.

Gassman, P. W., Jha, M., Wolter, C., and Schilling, K.: Evaluation of alternative cropping and nutrient management systems with Soil and Water Assessment tool for the Raccoon River Watershed Master Plan, American Journal of Environmental Sciences, 11, 227-244, doi:10.3844/ajessp.2015.227.244, 2015.

Goldstein, J. C. and Tarhule, A.: Evaluating the impacts of climate change and switchgrass production on a semiarid basin, Hydrol. Process., 29, 724-738, doi:10.1002/hyp.10159, 2015.

Guse, B., Kail, J., Radinger, J., Schröder, M., Kiesel, J., Hering, D., Wolter, C., and Fohrer, N.: Eco-hydrologic model cascades: Simulating land use and climate change impacts on hydrology, hydraulics and habitats for fish and macroinvertebrates, Sci. Total Environ., 533, 542-556, doi:10.1016/j.scitotenv.2015.05.078, 2015.

Heffernan, J. B., Soranno, P. A., Angilletta, M. J., Buckley, L. B., Gruner, D. S., Keitt, T. H., Kellner, J. R., Kominoski, J. S., Rocha, A. V., Xiao, J., Harms, T. K., Goring, S. J., Koenig, L. E., McDowell, W. H., Powell, H., Richardson, A. D., Stow, C. A., Vargas, R., and Weathers, K. C.: Macrosystems ecology: understanding ecological patterns and processes at continental scales, Front. Ecol. Environ., 12, 5-14, doi:10.1890/130017, 2014.

Hoque, Y. M., Raj, C., Hantush, M. M., Chaubey, I., and Govindaraju, R. S.: How do land-use and climate change affect watershed health? A scenario-based analysis, J. Water Qual. Expo. Health, 6, 19-33, doi:10.1007/s12403-013-0102-6, 2014.

Howells, M., Hermann, S., Welsch, M., Bazilian, M., Segerström, R., Alfstad, T., Gielen, D., Rogner, H., Fischer, G., van Velthuizen, H., Wiberg, D., Young, C., Roehr, R. A., Mueller, A., Steduto, P., and Ramma, I.: Integrated analysis of climate change, land-use, energy and water strategies, Nature Climate Change, 3, 621-626, doi:10.1038/NCLIMATE1789, 2013.

Jha, M. and Gassman, P. W.: Changes in hydrology and streamflow as predicted by modeling experiment forced with climate models, Hydrol. Process., 28, 2772-2781, doi:10.1002/hyp.9836, 2014.

Jha, M., Arnold, J. G., Gassman, P. W., Giorgi, F., and Gu, R. R.: Climate Change Sensitivity Assessment on Upper Mississippi River basin Streamflows Using SWAT, J. Am. Water Resour. As., 42, 997-1015, doi:10.1111/j.1752-1688.2006.tb04510.x, 2006.

Jha, M. K., Wolter, C. F., Schilling, K. E., and Gassman, P. W.: Assessment of total maximum daily load implementation strategies for nitrate impairment of the Raccoon River, Iowa, J. Environ. Qual., 39, 1317-1327, doi:10.2134/jeq2009.0392, 2010.

Ji, D., Wang, L., Feng, J., Wu, Q., Cheng, H., Zhang, Q., Yang, J., Dong, W., Dai, Y., Gong, D., Zhang, R.-H., Wang, X., Liu, J., Moore, J. C., Chen, D., and Zhou, M.: Description and basic evaluation of Beijing Normal University Earth System Model (BNU-ESM) version 1, Geosci. Model Dev., 7, 2039-2064, doi:10.5194/gmd-7-2039-2014, 2014.

Jungclaus, J. H., Lorenz, S. J., Timmreck, C., Reick, C. H., Brovkin, V., Six, K., Segschneider, J., Giorgetta, M. A., Crowley, T. J., Pongratz, J., Krivova, N. A., Vieira, L. E., Solanki, S. K., Klocke, D., Botzet, M., Esch, M., Gayler, V., Haak, H., Raddatz, T. J., Roeckner, E., Schnur, R., Widmann, H., Claussen, M., Stevens, B., and Marotzke, J.: Climate and carbon-cycle variability over the last millennium, Clim. Past, 6, 723-737, doi:10.5194/cp-6723-2010, 2010.

Keshwani, D. R. and Cheng, J. J.: Switchgrass for bioethanol and other value-added applications: A review, Bioresource Technol., 100, 1515-1523, doi:10.1016/j.biortech.2008.09.035, 2009.

Khanna, M., Dhungana, B., and Clifton-Brown, J.: Costs of producing miscanthus and switchgrass for bioenergy in Illinois, Biomass Bioenerg., 32, 482-493, doi:10.1016/j.biombioe.2007.11.003, 2008.

Kharin, V. V. and Zwiers, F. W.: Changes in the extremes in an ensemble of transient climate simulations with a coupled atmosphere-ocean GCM, J. Climate, 13, 3760-3788, 2000.

Kim, H. K., Parajuli, P. B., and Filip To, S. D.: Assessing impacts of bioenergy crops and climate change on hydrometeorology in the Yazoo River Basin, Mississippi, Agr. Forest Meteorol., 169, 61-73, 2013.

Kirkevåg, A., Iversen, T., Seland, Ø., Debernard, J. B., Storelvmo, T., and Kristjansson, J. E.: Aerosol-Cloud-Climate Interactions in the Climate Model CAM-Oslo, Tellus A, 60, 492-512, doi:10.1111/j.1600-0870.2008.00313.x, 2008.

Knutti, R., Furrer, R., Tebaldi, C., Cermak, J., and Meehl, G. A.: Challenges in Combining Projections from Multiple Climate Models, J. Climate, 23, 2739-2758, doi:10.1175/2009JCLI3361.1, 2010.

Krysanova, V. and White, M.: Advances in water resources assessment with SWAT - an overview, Hydrolog. Sci. J., 60, 771-783, doi:10.1080/02626667.2015.1029482, 2015.

Kundzewicz, Z. W., Mata, L. J., Arnell, N., Döll, P., Kabat, P., Jiménez, B., Miller, K., Oki, T., Şen, Z., and Shiklomanov, I.: Freshwater resources and their management, Climate Change 2007: Impacts, Adaptation and Vulnerability, Contribution of Working Group II to the Fourth Assessment Report of the Intergovernmental Panel on Climate Change, edited by: Parry, M. L., Canziani, O. F., Palutikof, J. P., van der Linden, P. J., and Hanson, C. E., Cambridge University Press, UK, 173-210, 2007.

Li, D., Tian, Y., Liu, C., and Hao, F.: Impact of land-cover and climate changes on runoff of the source regions of the Yellow River, J. Geogr. Sci., 14, 330-338, Doi: 10.1007/BF02837414, 2004.

Liu, G. H., Luan, Z. Q., Yan, B. X., Guo, Y. D., and Wang, Z. X.: Response of hydrological processes to land use change and climate variability in the Upper Naoli River Watershed, Northeast China, Water Resour., 42, 438-447, doi:10.1134/S0097807815040077, 2015.

Liu, W., Zhang, A., Wang, L., Fu, G., Chen, D., Liu, C., and Cai, T.: Projecting streamflow in the Tangwang River basin (China) using 
a rainfall generator and two hydrological models, Clim. Res., 62, 79-97, doi:10.3354/cr01261, 2015.

Martre, P., Wallach, D., Asseng, S., Ewert, F., Jones, J. W., Rötter, R. P., Boote, K. J., Ruane, A. C., Thorburn, P. J., Cammarano, D., Hatfield, J. L., Rosenzweig, C., Aggarwal, P. K., Angulo, C., Basso, B., Bertuzzi, P., Biernath, C., Brisson, N., Challinor, A. J., Doltra, J., Gayler, S., Goldberg, R., Grant, R. F., Heng, L., Hooker, J., Hunt, L. A., Ingwersen, J., Izaurralde, R. C., Kersebaum, K. C., Müller, C., Kumar, S. N., Nendel, C., O'leary, G., Olesen, J. E., Osborne, T. M., Palosuo, T., Priesack, E., Ripoche, D., Semenov, M. A., Shcherbak, I., Steduto, P., Stöckle, C. O., Stratonovitch, P., Streck, T., Supit, I., Tao, F., Travasso, M., Waha, K., White, J. W., and Wolf, J.: Multimodel ensembles of wheat growth: many models are better than one, Glob. Change Biol., 21, 911-925, doi:10.1111/gcb.12768, 2015.

McLaughlin, S. B. and Kszos, L. A.: Development of switchgrass (Panicum virgatum) as a bioenergy feedstock in the United States, Biomass Bioenerg., 28, 515-535, 2005.

Mehdi, B., Lehner, B., Gombault, C., Michaud, A., Beaudin, I., Sottile, M.-F., and Blondlot, A.: Simulated impacts of climate change and agricultural land use change on surface water quality with and without adaptation management strategies, Agr. Ecosyst. Environ., 213, 47-60, doi:10.1016/j.agee.2015.07.019, 2015a.

Mehdi, B., Ludwig, R., and Lehner, B.: Evaluating the impacts of climate change and crop land use change on streamflow, nitrates and phosphorus: A modeling study in Bavaria, J. Hydrol.Regional Studies, 4, 60-90, doi:10.1016/j.ejrh.2015.04.009, 2015b.

Melillo, J. M., Reilly, J. M., Kicklighter, D. W., Gurgel, A. C., Cronin, T. W., Paltsev, S., Felzer, B. S., Wang, X., Sokolov, A. P., and Schlosser, C. A.: Indirect Emissions from Biofuels: How Important?, Science, 326, 1397-1399, doi:10.1126/science.1180251, 2009.

Miao, R., Khanna, M., and Huang, H.: Responsiveness of Crop Yield and Acreage to Prices and Climate, Am. J. Agr. Econ., 98, 191-211, doi:10.1093/ajae/aav025, 2015.

Moore, N., Alagarswamy, G., Pijanowski, B., Thornton, P., Lofgren, B., Olson, J., Andresen, J., Yanda, P., and Qi, J.: East African food security as influenced by future climate change and land use change at local to regional scales, Climatic Change, 110, 823844, doi:10.1007/s10584-011-0116-7, 2012.

Moss, R. H., Edmonds, J. A., Hibbard, K. A., Manning, M. R., Rose, S. K., van Vuuren, D. P., Carter, T. R., Emori, S., Kainuma, M., Kram, T., Meehl, G. A., Mitchell, J. F. B., Nakicenovic, N., Riahi, K., Smith, S. J., Stouffer, R. J., Thomson, A. M., Weyant, J. P., and Wilbanks, T. J.: The next generation of scenarios for climate change research and assessment, Nature, 463, 747-756, doi:10.1038/nature08823, 2010.

Neitsch, S. L., Arnold, J. G., Kiniry, J. R., Srinivasan, R., and Williams, J. R.: Soil and Water Assessment Tool Theoretical Documentation, Version 2009, Texas Water Resources Institute, Temple, TX, USA, TR-406, 2011.

Neupane, R. P. and Kumar, S.: Estimating the effects of potential climate and land use changes on hydrologic processes of a large agriculture dominated watershed, J. Hydrol., 529, 418-429, doi:10.1016/j.jhydrol.2015.07.050, 2015.

Öborn, I., Magnusson, U., Bengtsson, J., Vrede, K., Fahlbeck, E., Jensen, E. S., Westin, C., Jansson, T., Hedenus, F., Lindholm, S.
H., Stenström, M., Jansson, B., and Rydhmer, L.: Five Scenarios for 2050 - Conditions for Agriculture and land use, Uppsala, Swedish University of Agricultural Sciences, ISBN: 978-91-5769032-6, 2011.

Ostberg, S., Schaphoff, S., Lucht, W., and Gerten, D.: Three centuries of dual pressure from land use and climate change on the biosphere, Environ. Res. Lett., 10, 044011, doi:10.1088/17489326/10/4/044011, 2015.

Panagopoulos, Y., Gassman, P. W., Arritt, R. W., Herzmann, D. E., Campbell, T. D., Valcu, A., Jha, M. K., Kling, C. L., Srinivasan, R., White, M., and Arnold, J. G.: Impacts of climate change on hydrology, water quality and crop productivity in the Ohio-Tennessee River Basin, Int. J. Agric. Biol. Eng., 8, 36-53, doi:10.3965/j.ijabe.20150803.1497, 2015.

Parajuli, P. B. and Duffy, S. E.: Quantifying Hydrologic and Water Quality Responses to Bioenergy Crops in Town Creek Watershed in Mississippi, Journal of Sustainable Bioenergy Systems, 3, 202-208, doi:10.4236/jsbs.2013.33028, 2013.

Parajuli, P. B., Jayakody, P., Sassenrath, G. F., Ouyang, Y., and Pote, J. W.: Assessing the impacts of crop-rotation and tillage on crop yields and sediment yield using a modeling approach, Agr. Water Manage., 119, 32-42, doi:10.1016/j.agwat.2012.12.010, 2013.

PCMDI: About the WCRP CMIP3 Multi-Model Dataset Archive at PCMDI, Program for Climate Model Diagnosis and Intercomparison (PCMDI), Lawrence Livermore National Laboratory, US Department of Energy, Livermore, CA, available at: http://www-pcmdi.llnl.gov/ipcc/about_ipcc.php (last access: 11 June 2014), 2016.

Peplow, M.: Cellulosic ethanol fights for life: Pioneering biofuel producers hope that US government largesse will ease their way into a tough market, Nature, 507, 152-153, doi:10.1038/507152a, 2014.

Pierce, D. W., Barnett, T. P., Santer, B. D., and Gleckler, P. J.: Selecting Global Climate Models for Regional Climate Change Studies, P. Natl. Acad. Sci. USA, 106, 8441-8446, 2009.

RFA: Renewable Fuels Association. Fueling a High Octane Future: 2016 Ethanol Industry Outlook, Washington D.C., available at: http://www.ethanolrfa.org/wp-content/uploads/2016/02/ Ethanol-Industry-Outlook-2016.pdf, last access: 9 February 2016.

Riahi, K., Rao, S., Krey, V., Cho, C., Chirkov, V., Fischer, G., Kindermann, G., Nakicenovic, N., and Rafaj, P.: RCP 8.5 - A scenario of comparatively high greenhouse gas emissions, Climatic Change, 109, 33-57, doi:10.1007/s10584-011-0149-y, 2011.

Sayasane, R., Kawasaki, A., Shrestha, S., and Takamatsu, M.: Assessment of potential impacts of climate and land use changes on stream flow: A case study of the Nam Xong Watershed in Lao PDR, Journal of Water and Climate Change, 7, 184-197, doi:10.2166/wcc.2015.050, 2015.

Schilling, K. E., Jha, M. K., Zhang, Y.-K., Gassman, P. W., and Wolter, C. F.: Impact of Land Use and Land Cover Change on the Water Balance of a Large Agricultural Watershed: Historical Effects and Future Directions, Water Resour. Res., 44, W00A09, doi:10.1029/2007WR006644, 2008.

Schlenker, W. and Roberts, M. J.: Estimating the Impact of Climate Change on Crop Yields: The Importance of Nonlinear Temperature Effects, National Bureau of Economic Research, available at: http://www.nber.org/papers/w13799 (last access: 22 June 2015), 2008. 
Schumer, M. R., Vogel, K. P., Mitchell, R. B., and Perrin, R. K.: Net energy of cellulosic ethanol from switchgrass, P. Natl. Acad. Sci. USA, 105, 464-469, 2008.

Schoof, J. T.: High-resolution projections of 21 st century daily precipitation for the contiguous U.S., J. Geophys. Res.-Atmos., 120, 3029-3042, doi:10.1002/2014JD022376, 2015.

Schoof, J. T., Pryor, S. C., and Robeson, S. M.: Downscaling Daily Maximum and Minimum Temperatures in the Midwestern USA: A Hybrid Empirical Approach, Int. J. Climatol., 27, 439-454, doi:10.1002/joc.1412, 2007.

Schoof, J. T., Pryor, S. C., and Surprenant, J.: Development of daily precipitation projections for the United States based on probabilistic downscaling, J. Geophys. Res., 115, D13106, doi:10.1029/2009JD013030, 2010.

Secchi, S., Tyndall, J., Schulte, L. A., and Asbjornsen, H.: High crop prices and conservation Raising the Stakes, J. Soil Water Conserv., 63, 68A-73A, 2008.

Secchi, S., Gassman, P. W., Jha, M., Kurkalova, L., and Kling, C. L.: Potential water quality changes due to corn expansion in the Upper Mississippi River Basin, Ecol. Appl., 21, 1068-1084, 2011.

Serpa, D., Nunes, J. P., Santos, J., Sampaio, E., Jacinto, R., Veiga, S., Lima, J. C., Moreira, M., Corte-Real, J., Keizer, J. J., and Abrantes, N.: Impacts of climate and land use changes on the hydrological and erosion processes of two contrasting Mediterranean catchments, Sci. Total Environ., 538, 64-77, doi:10.1016/j.scitotenv.2015.08.033, 2015.

Simpson, T. W., Sharpley, A. N., Howarth, R. W., Paerl, H. W., and Mankin, K. R.: The new gold rush: Fueling ethanol production while protecting water quality, J. Environ. Qual., 37, 318-324, doi:10.2134/jeq2007.0599, 2008.

Singkran, N., Tosang, J., Waijaroen, D., Intharawichian, N., Vannarart, O., Anuntawong, P., Kunta, K., Wisetsopa, P., Tipvong, T., Janjirawuttikul, N., Masthawee, F., Anornpatanawat, S., and Kirtsaeng, S.: Influences of land use and climate changes on hydrologic system in the northeastern river basin of Thailand, Journal of Water and Climate Change, 6, 325-340, doi:10.2166/wcc.2014.127, 2015.

Stubbs, M.: Conservation Provisions in the 2014 Farm Bill (P.L. 113-79) Congressional Research Service Report R43504, Washington D.C., 2014.

Tan, M. L., Ibrahim, A. L., Yusop, Z., Duan, Z., and Ling, L.: Impacts of land-use and climate variability on hydrological components in the Johor River basin, Malaysia, Hydrolog. Sci. J., 60, 873-889, doi:10.1080/02626667.2014.967246, 2015.

Taylor, K. E., Stouffer, R. J., and Meehl, G. A.: An Overview of CMIP5 and the Experiment Design, B. Am. Meteorol. Soc., 93, 485-498, doi:10.1175/BAMS-D-11-00094.1, 2012.

Teshager, A. D., Misgna, G., Gassman, P. W., Secchi, S., and Schoof, J. T.: Modeling Agricultural Watersheds with the Soil and Water Assessment Tool (SWAT): Calibration and validation with a novel procedure for spatially explicit HRUs, Environ. Manage., 57, 894-911, doi:10.1007/s00267-015-0636-4, 2015.

Thomson, A. M., Calvin, K. V., Smith, S. J., Kyle, G. P., Volke, A., Patel, P., Delgado-Arias, S., Bond-Lamberty, B., Wise, M. A., Clarke, L. E., and Edmonds, J. A.: RCP4.5: a pathway for stabilization of radiative forcing by 2100 , Climatic Change, 109 , 77-94, doi:10.1007/s10584-011-0151-4, 2011.

Tilman, D., Balzer, C., Hill, J., and Befort, B. L.: Global food demand and the sustainable intensification of agri- culture, P. Natl. Acad. Sci. USA, 108, 20260-20264, doi:10.1073/pnas.1116437108, 2011.

Tomer, M. D., Moorman, T. B., James, D. E., Hadish, G., and Rossi, C. G.: Assessment of the Iowa River's south fork watershed: part 2: conservation practices, J. Soil Water Conserv., 63, 371-379, 2008.

Trybula, E. M., Cibin, R., Burks, J. L., Chaubey, I., Brouder, S. M., and Volenec, J. J.: Perennial rhizomatous grasses as bioenergy feedstock in SWAT: Parameter development and model improvement, Glob. Change Biol., 7, 1185-1202, doi:10.1111/gcbb.12210, 2015.

Ummenhofer, C. C., Xu, H., Twine, T. E., Girvetz, E. H., McCarthy, H. R., Chhetri, N., and Nicholas, K. A.: How Climate Change Affects Extremes in Maize and Wheat Yield in Two Cropping Regions, J. Climate, 28, 4653-4687, doi:10.1175/JCLI-D-13$00326.1,2015$.

USDA-NASS: National Agricultural Statistics Service, CropScape Cropland Data Layer: Web interface, United States Department of Agriculture, 2012.

USDA-NASS: National Agricultural Statistics Service, Agricultural Statistics Board, United States Department of Agriculture, ISSN: 1936-3737, 2015.

USGS: Federal Standards and Procedures for the National Watershed Boundary Dataset (WBD), Techniques and Methods 11A3, chap. 3 of Section A, Federal Standards Book 11, Collection and Delineation of Spatial Data. Techniques and Methods 11A3, Fourth Ed. US Department of the Interior, US Geological Survey, Reston, VA and US Department of Agriculture, Natural Resources Conservation Service, Washington, D.C., available at: http://pubs.usgs.gov/tm/11/a3/ (last access: 23 January 2016), 2013.

Vadas, P. A., Barnett, K. H., and Undersander, D. J.: Economics and Energy of Ethanol Production from Alfalfa, Corn, and Switchgrass in the Upper Midwest, USA, BioEnergy Research, 1, 4455, doi:10.1007/s12155-008-9002-1, 2008.

van Vuuren, D. P., Edmonds, J., Kainuma, M., Riahi, K., Thomson, A., Hibbard, K., Hurtt, G. C., Kram, T., Krey, V., Lamarque, J.-F., Matsui, T., Meinshausen, M., Nakicenovic, N., Smith, S. J., and Rose, S. K.: Representative concentration pathways: an overview, Climatic Change, 109, 5-31, doi:10.1007/s10584-0110148-z, 2011a.

van Vuuren, D. P., Stehfest, E., Den Elzen, M. G. J., Deetman, S., Hof, A., Isaac, M., Klein Goldewijk, K., Kram, T., Mendoza Beltran, A., Oostenrijk, R., Van Vliet, J., and Van Ruijven, B.: RCP2.6: exploring the possibility to keep global mean temperature change below 2 degrees, Climatic Change, 109, 95-116, doi:10.1007/s10584-011-0152-3, $2011 \mathrm{~b}$.

Voldoire, A., Sanchez-Gomez, E., y Mélia, D. S., Decharme, B., Cassou, C., Sénési, S., Valcke, S., Beau, I., Alias, A., Chevallier, M., Déqué, M., Deshayes, J., Douville, H., Fernandez, E., Madec, G., Maisonnave, E., Moine, M.-P., Planton, S., SaintMartin, D., Szopa, S., Tyteca, S., Alkama, R., Belamari, S., Braun, A., Coquart, L., and Chauvin, F.: The CNRM-CM5.1 Global Climate Model: Description and Basic Evaluation, Clim. Dynam., 40, 2091-2121, doi:10.1007/s00382-011-1259-y, 2013.

Weigel, A. P., Knutti, R., Liniger, M. A., and Appenzeller, C.: Risks of Model Weighting in Multimodel Climate Projections, J. Climate, 23, 4175-4191, doi:10.1175/2010JCLI3594.1, 2010. 
White, V.: Agriculture and drinking water supplies: Removing nitrates from drinking water in Des Moines, Iowa, J. Soil Water Conserv., 51, 454-455, 1996.

Williams, J. R., Arnold, J. G., Kiniry, J. R., Gassman, P. W., and Green, C. H.: History of model development at Temple, Texas, Hydrolog. Sci. J., 53, 948-960, doi:10.1623/hysj.53.5.948, 2008.

Wilson, C. O. and Weng, Q.: Simulating the impacts of future land use and climate changes on surface water quality in the Des Plaines River watershed, Chicago Metropolitan Statistical Area, Illinois, Sci. Total Environ., 409, 4387-4405, doi:10.1016/j.scitotenv.2011.07.001, 2011.

Wright, C. K. and Wimberly, M. C.: Recent land use change in the Western Corn Belt threatens grasslands and wetlands, P. Natl. Acad. Sci., 110, 4134-4139, doi:10.1073/pnas.1215404110, 2013.

Wu, M., Demissie, Y., and Yan, E.: Simulated impact of future biofuel production on water quality and water cycle dynamics in the Upper Mississippi river basin, Biomass Bioenerg., 41, 4456, doi:10.1016/j.biombioe.2012.01.030, 2012.

Wu, T., Yu, R., Zhang, F., Wang, Z., Dong, M., Wang, L., Jin, X., Chen, D., and Li, L.: The Beijing Climate Center Atmospheric General Circulation Model: Description and Its Performance for the Present-Day Climate, Clim. Dynam., 34, 123-47, doi:10.1007/s00382-008-0487-2, 2010.

Wu, Y., Liu, S., and Abdul-Aziz, O. I.: Hydrological effects of the increased $\mathrm{CO}_{2}$ and climate change in the Upper Mississippi River Basin using a modified SWAT, Climatic Change, 110, 9771003, doi:10.1007/s10584-011-0087-8, 2012.

Wu, Y., Liu, S., Sohl, T. L., and Young, C. J.: Projecting the land cover change and its environmental impacts in the Cedar River Basin in the Midwestern United States, Environ. Res. Lett., 8, 024025, doi:10.1088/1748-9326/8/2/024025, 2013.
Wu, F., Zhan, J., Su, H., Yan, H., and Ma, E.: Scenario-based impact assessment of land use/cover and climate changes on watershed hydrology in Heihe River Basin of northwest China, Advances in Meteorology, 2015, 410198, doi:10.1155/2015/410198, 2015.

Yukimoto, S., Adachi, Y., Hosaka, M., Sakami, T., Yoshimura, H., Hirabara, M., Tanaka, T. A., Shindo, E., Tsujino, H., Deushi, M., Mizuta, R., Yabu, S., Obata, A., Nakano, H., Koshiro, T., Ose, T., and Kitoh, A.: A New Global Climate Model of the Meteorological Research Institute: MRI-CGCM3-Model Description and Basic Performance, J. Meteorol. Soc. Jpn., 90A, 23-64, doi:10.2151/jmsj.2012-A02, 2012.

Zhang, L., Nan, Z., Yu, W., and Ge, Y.: Modeling land-use and land-cover change and hydrological responses under consistent climate change scenarios in the Heihe River Basin, China, Water Resour. Manag., 29, 4701-4717, doi:10.1007/s11269-015-10859, 2015.

Zhang, L., Nan, Z., Yu, W., and Ge, Y.: Hydrological responses to land-use change scenarios under constant and changed climatic conditions, Environ. Manage., 57, 412-431, doi:10.1007/s00267-015-0620-z, 2016.

Zhou, X. V., Clark, C. D., Nair, S. S., Hawkins, S. A., and Lambert, D. M.: Environmental and economic analysis of using SWAT to simulate the effects of switchgrass production on water quality in an impaired watershed, Agr. Water Manage., 160, 1-13, doi:10.1016/j.agwat.2015.06.018, 2015.

Zuo, D., Xu, Z., Yao, W., Jin, S., Xiao, P., and Ran, D.: Assessing the effects of changes in land use and climate on runoff and sediment yields from a watershed in the Loess Plateau of China, Sci. Total Environ., 544, 238-250, doi:10.1016/j.scitotenv.2015.11.060, 2016. 